\title{
HIV-1 Envelope Protein gp120 Promotes Proliferation and the Activation of Glycolysis in Glioma Cell
}

\author{
Gabriel Valentín-Guillama ${ }^{1}$, Sheila López ${ }^{2}$, Yuriy V. Kucheryavykh ${ }^{1}$, Nataliya E. Chorna ${ }^{3}$, \\ Jose Pérez ${ }^{1}$, Jescelica Ortiz-Rivera ${ }^{1}$, Michael Inyushin ${ }^{4}$ (D), Vladimir Makarov ${ }^{5}$, \\ Aníbal Valentín-Acevedo ${ }^{6}$ (i), Alfredo Quinones-Hinojosa ${ }^{7}$, Nawal Boukli ${ }^{2}$ and \\ Lilia Y. Kucheryavykh ${ }^{1, *}$ \\ 1 Department of Biochemistry, Universidad Central del Caribe, School of Medicine, Ave. Laurel, Santa Juanita, \\ Bayamon, PR 00956, USA; gabriel.valentin2@upr.edu (G.V.-G.); yuriy.kucheryavykh@uccaribe.edu (Y.V.K.); \\ 115jperez@uccaribe.edu (J.P.); jescelica.ortiz@upr.edu (J.O.-R.) \\ 2 Biomedical Proteomics Facility, Department of Microbiology and Immunology, Universidad Central del \\ Caribe, School of Medicine, Ave. Laurel, Santa Juanita, Bayamon, PR 00956, USA; \\ sheila_natalie@yahoo.com (S.L.); nawal.boukli@uccaribe.edu (N.B.) \\ 3 Department of Biochemistry, University of Puerto Rico, School of Medicine, San Juan, PR 00936, USA; \\ nataliya.chorna@upr.edu \\ 4 Department of Physiology, Universidad Central del Caribe, School of Medicine, Ave. Laurel, Santa Juanita, \\ Bayamon, PR 00956, USA, mikhail.inyushin@uccaribe.edu \\ 5 Department of Physics, University of Puerto Rico, Río Piedras Campus, San Juan, PR 00931, USA; \\ vmvimakarov@gmail.com \\ 6 Department of Microbiology and Immunology, Universidad Central del Caribe, School of Medicine, Ave. \\ Laurel, Santa Juanita, Bayamon, PR 00956, USA; anibal.valentin@uccaribe.edu \\ 7 Department of Neurologic Surgery, Mayo Clinic, 4500 San Pablo Road South, Jacksonville, FL 32224, USA; \\ quinones-hinojosa.alfredo@mayo.edu \\ * Correspondence: lilia.kucheryavykh@uccaribe.edu; Tel.: +1-787-798-3001 (ext. 2037)
}

Received: 19 July 2018; Accepted: 30 August 2018; Published: 1 September 2018

\begin{abstract}
Patients infected with human immunodeficiency virus (HIV) are more prone to developing cancers, including glioblastomas (GBMs). The median survival for HIV positive GBM patients is significantly shorter than for those who are uninfected, despite the fact that they receive the same treatments. The nature of the GBM-HIV association remains poorly understood. In this study, we analyzed the effect of the HIV envelope glycoprotein gp120 on GBM cell proliferation. Specifically, we performed cell cycle, western blot, protein synthesis and metabolomics analysis as well as ATP production and oxygen consumption assays to evaluate proliferation and metabolic pathways in primary human glioma cell line, U87, A172 cells and in the HIVgp120tg/GL261 mouse model. Glioma cells treated with gp120 (100 ng/mL for 7-10 days) showed higher proliferation rates and upregulation in the expression of enolase 2, hexokinase and glyceraldehyde-3-phosphate dehydrogenase when compared to untreated cells. Furthermore, we detected an increase in the activity of pyruvate kinase and a higher glycolytic index in gp120 treated cells. Gp120 treated GBM cells also showed heightened lipid and protein synthesis. Overall, we demonstrate that in glioma cells, the HIV envelope glycoprotein promotes proliferation and activation of glycolysis resulting in increased protein and lipid synthesis.
\end{abstract}

Keywords: glioma; HIV; gp120; glycolysis

\section{Introduction}

Patients infected with human immunodeficiency virus (HIV) are more predisposed to developing cancer, including glioblastoma (GBM) [1,2] and ten percent of patients with acquired immune deficiency 
syndrome (AIDS) have brain tumors. Although the majority of these tumors are central nervous system lymphomas, glioma tumors arise as well [3]. Multiple medical reports in HIV / AIDS patients indicate that GBM occurs at a higher frequency (5.4- to 45-fold increase) [4-7] and at a younger age [8] in individuals at various stages of HIV infection than in the general population. On average, GBM tumors appear approximately 3 years after initial HIV infection [2]. Additionally, the median survival rate in GBM-HIV-infected patients is shorter (an average of 8 months) than in GBM-non-infected patients (an average of 14 months) despite receiving the same treatment $[2,3,9,10]$. CD4+ cell count at initial diagnosis of GBM is not correlated with survival suggesting that increased aggressive tumor behavior is not a direct outcome of immune deficiency [8].

The nature of the GBM-HIV relationship is not well understood. The stimulatory effect of HIV infection on glioma tumor development has been associated with reduced immune surveillance [11,12]. However, immune incompetence has not been clearly shown to underlay glioma tumor development and progression $[7,13,14]$. While the incidence of some malignancies among HIV-infected individuals has declined with Highly Active Antiretroviral Therapy (HAART), it remains elevated compared with uninfected population suggesting that overall immune deficiency is not the only cause [15-17]. Moreover, HIV is not found in glioma tissues of patients diagnosed with GBM [2]. It has been shown that some human GBM cell lines have the ability to suppress HIV infection by secreting molecules that inhibit HIV attachment to target cells, while other GBM cell lines do not [18]. The predominant HIV target cells in the brain are microglia and macrophages, while other cells such as astrocytes, oligodendrocytes, neurons and microvascular cells tend to be mostly resistant [19-21].

It has been shown that HIV infection promotes the development of glial tumors through a set of factors that includes the activation of oncogenes, the impairment of immune defenses and the production of growth factors and cytokines capable of inducing astrocytosis [21-24]. Additionally, tumor cells can be directly exposed to HIV proteins such as gp120, which can be secreted by infiltrated and infected microglia and astrocytes $[25,26]$.

HIV is believed to enter and infect the central nervous system through the interaction between the envelope protein gp120 and the CCR5 or CXCR4 receptors expressed on macrophages but some neurons and astrocytes are thought to express these receptors as well, which can result in their subsequent infection $[3,24]$. GBM cells can also express CXCR4 and CCR5 and activation of these receptors is known to promote cell survival and cell cycle progression [27-31]. We hypothesize that despite some innate resistance to HIV infection, glioma cells can interact with the HIV envelope protein gp120 and this interaction promotes cell proliferation and tumor growth.

In this study, we investigated the effect of the HIV envelope protein gp120 on glioma cell growth and survival. We showed that continuous treatment of the U87 and A172 glioma cells and the primary human glioma cell line 965 with gp120 for a period of 10 days resulted in increased proliferation, migration and survival. Through a combination of western blot and metabolomics analysis we also detected the activation of glycolysis as well as protein and fatty acid synthesis metabolic pathways in these cells. Finally, using a HIVgp120tg/Gl261 mouse glioma implantation model, we demonstrated that animals expressing gp120 in their brain develop bigger tumors and have shorter median survival than their wild type littermates (WT).

\section{Results}

\subsection{Gp120 Stimulates Proliferation and Migration in Glioma Cells}

Our initial observations on the effect of gp120 in the proliferation of glioma cells came from a trypan blue exclusion assay. After treating cells with gp120 at $100 \mathrm{ng} / \mathrm{mL}$ for 10 continuous days we observed an increase in the number of viable cells in all cell lines investigated, including the 965 primary glioma cell line (Figure 1A). The gp120 concentration we used has been reported in the literature as effective for inducing signaling in glioma cells and it is also consistent with the gp120 serum concentration in HIV patients [32,33]. A significant difference in cell growth between 
gp120-treated and untreated cells was not observed at earlier time points (less than 5 days of treatment) (Supplemental Figure S1A). In addition, 965 cells showed a reduction in the amount of cell death (Figure 1B). This effect on cell survival was not observed in other cancer cell lines tested, including Jurkat T cells, in where gp120 showed instead a toxic effect (Supplemental Figure S2).

A
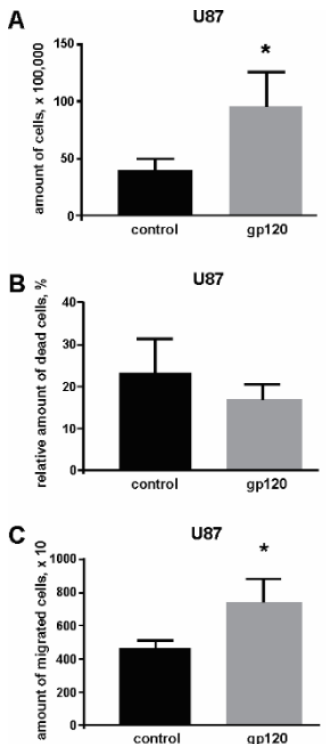

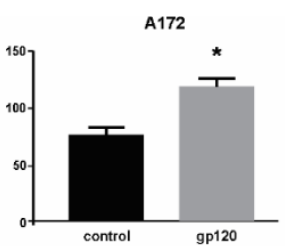

A172
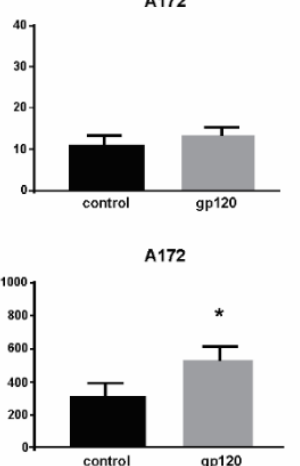

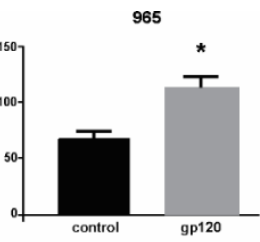

965
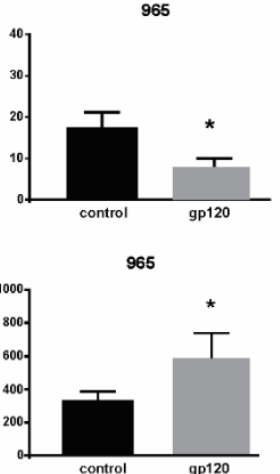

D
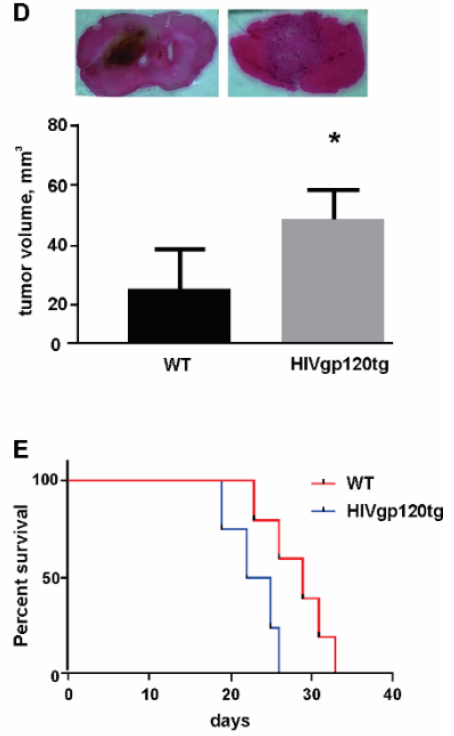

Figure 1. gp120 stimulates viability and migration and reduces cell death in glioma cells. Experiments were performed for untreated glioma cells and cells continuously treated with gp120 for 10 days. U87 and A172 cell lines and 965 primary glioma cells were investigated. Live and dead cells were counted with the use of trypan blue staining. (A) Cell viability was evaluated as the total number of live cells. (B) The proportion of dead cells was evaluated as the percentage of the total number of cells. (C) Migration assays were performed using Transwell membranes for $5 \mathrm{~h}$ of migration toward $5 \%$ serum-containing medium in the lower compartment. The total number of cells that had migrated to the lower compartment was determined and is represented in the graph. (D) H\&E staining of brain sections encompassing glioma tumor and quantification of tumor size in wild type (WT) and HIVgp120tg mice. (E) Survival analysis, performed for WT and HIVgp120tg mice following GL261 glioma cells implantation. Mean \pm S.E. and significant differences from control $\left(^{*}\right)$ are shown $(p<0.05)$. Unpaired $t$-tests were used to determine the significance between groups. Comparison of survival curves was performed by use of long-rank Mantel-Cox test. Six repeated experiments $(n=6)$ were used for statistical analysis.

Treating glioma cells with gp120 also had a positive effect in migration. In a transwell migration assay, gp120-treated glioma cells showed a greater migration propensity than untreated cells (Figure 1C).

In vivo studies using the HIVgp120tg mice, which expresses the HIV gp120 glycoprotein in the central nervous system (CNS), demonstrated that upon implantation of GL261 mouse glioma cells animals develop bigger brain tumors compared to their WT littermates (Figure 1D). Additionally, HIVgp120tg mice had 15\% shorter survival rates (23.5 days) when compared to WT animals (27.5 days) (Figure 1E). This HIVgp120tg mouse model has been previously described and characterized [34-36]. Expression of gp120 in brain and implanted tumor in HIVgp120tg mice is shown in Supplemental Figure S3.

Cell cycle analysis using flow cytometry confirmed and further extended our results on cell proliferation showing that glioma cells treated with gp120 have a higher frequency of mitosis than untreated cells (Figure 2). Despite the different basal proliferation rates in the glioma cell lines investigated (the average percentage of cells at the G2/M phase of mitosis was $19 \pm 0.64 \%$ of the total 
number of cells for U87, $27 \pm 0.25 \%$ for A172 and $17 \pm 1.76 \%$ for 965 cells), a $7-10$-day treatment with gp120 resulted in an increase in the percentage of cells at the G2/M phase to $20.6 \pm 0.51 \%, 28.5 \pm 0.32$ and $18.8 \pm 1.6$, respectively $(n=4)$. Consequently, the average increase in the percentage of cells at the G2/M phase in gp120-treated cells over untreated cells was $1.6 \%$. For cells in the S phase we only observed a significant increase in A172 cells (18.2 $\pm 0.18 \%$ in untreated vs. $19.1 \pm 0.7 \%$ gp120-treated). U87 and 965 showed insignificant increase in this population in response to gp120 treatment (11.02 \pm 2 in untreated vs. $15.8 \pm 3.9$ in gp120-treated U87 cells and $11.73 \pm 0.2 \%$ in untreated vs. $15.4 \pm 3.6 \%$ in gp120-treated 956 cells). For all cell lines investigated, we observed no difference in response to gp120 in the number of cells in the sub-G1 phase, which is indicative of cell undergoing apoptosis. Taken together, our results demonstrate that the HIV-gp120 glycoprotein induces proliferation in glioma cells.

A
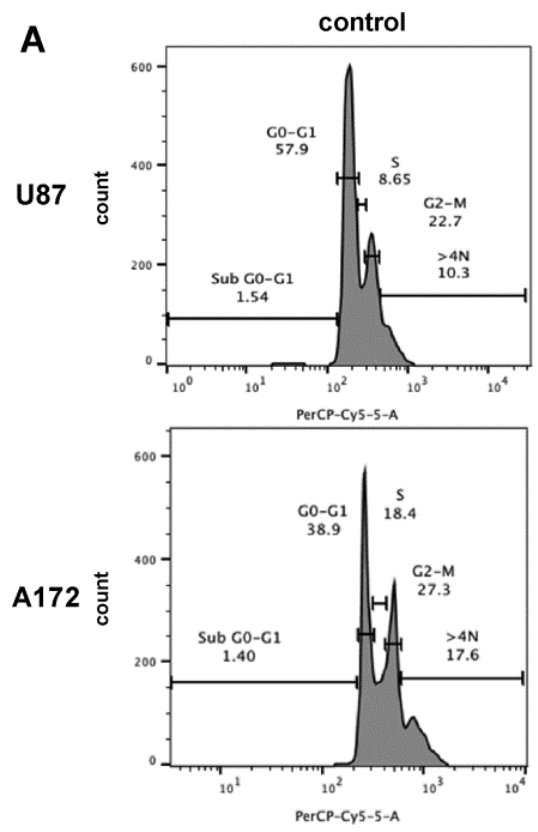

965

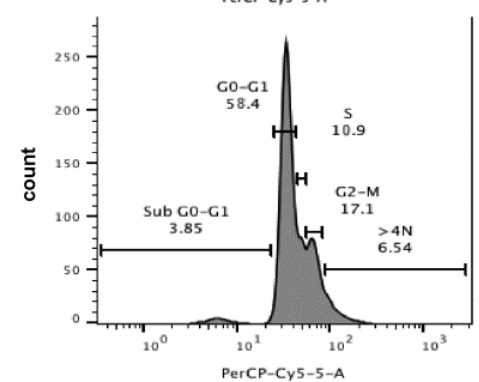

gp120
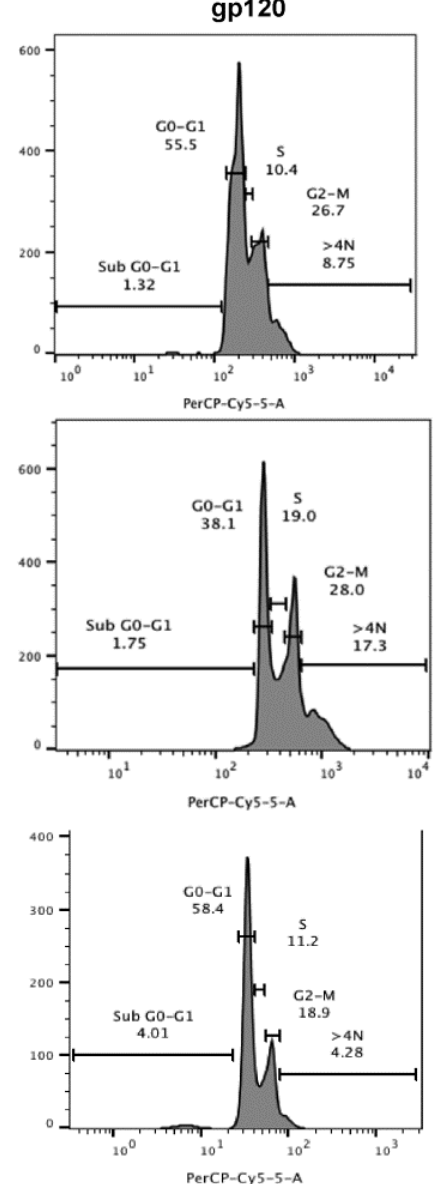

B
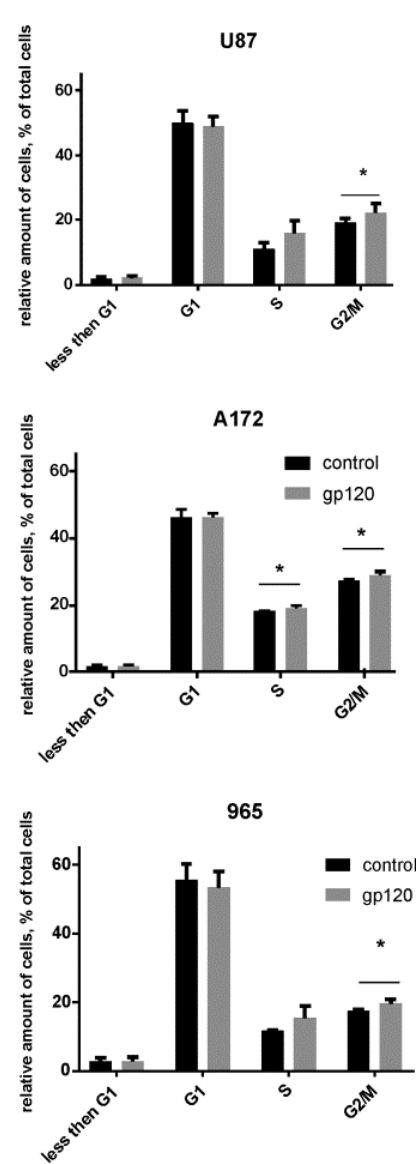

Figure 2. Gp120 stimulates proliferation of glioma cells. Cell cycle analysis was performed by analyzing cells stained with 7-aminoactinomycin D (7AAD) with flow cytometry. The percentage of cells in the G0/G1, S and G2/M phases was determined based on DNA content. Experiments were performed for untreated glioma cells and cells continuously treated with gp120 for 10 days. U87 and A172 cell lines and 965 primary glioma cells were investigated. (A) Histograms and (B) bar graphs represent the total distribution of cells at different phases of the cell cycle. The proportion of cells at each phase of mitosis is shown as a percentage of the total number of cells. Mean \pm S.E. and significant differences from control $\left(^{*}\right)$ are shown $(p<0.05)$. Unpaired $t$-tests were used to determine the significance between groups. Four repeated experiments $(n=4)$ were used for statistical analysis.

Based on these results we calculated the duplication time for cells treated with gp120 $\left(\tau_{1}\right)$ and untreated $\left(\tau_{2}\right)$.

During time $t_{0}$, the number of duplication events can be determined as follows: 


$$
N_{i}=\frac{t_{0}}{\tau_{i}} ; i=1,2 \text { (1gp120-treated, 2untreated cells) }
$$

Taking $n$ as the initial number of cells and $q_{1} / q_{2}$ as the ratio of cells at the G2/M phase with and without treatment with gp120, the final number of gp120-treated $\left(n_{1}\right)$ and untreated $\left(n_{2}\right)$ cells can be determined as follows:

$$
\begin{aligned}
& n_{i}=n+q_{i} n+q_{i}\left(n+q_{i} n\right)+q_{i}\left(n+q_{i} n+q_{i}\left(n+q_{i} n\right)\right) \\
& +q_{i}\left[n+q_{i} n+q_{i}\left(n+q_{i} n\right)+q_{i}\left(n+q_{i} n+q_{i}\left(n+q_{i} n\right)\right)\right] \\
& +. . \approx A_{i} e^{\alpha_{i} N_{i}} \\
& i=1,2 \\
& q_{1}=0.206 q_{2}=0.190
\end{aligned}
$$

The values of $q_{1}$ and $q_{2}$ were obtained through direct summation of cell populations $n_{i}$ created in each growth step, presented by the simplest kinetics model described earlier [37], where $\alpha_{i}$ is the parameter of kinetic model and $\mathrm{Ni}>>1$. Since we initiated the experiment with the same number of cells for both treated and untreated groups, A1 = A2. Thus, given that after 10 days the number of treated cells was twice the amount on the untreated group (Figure 1).

$$
\begin{aligned}
& \frac{n_{1}}{n_{2}}=e^{\alpha_{1} N_{1}-\alpha_{2} N_{2}}=e^{\alpha_{1} \frac{t_{0}}{\tau_{1}}-\alpha_{2} \frac{t_{0}}{\tau_{2}}}=e^{\left(\frac{1}{\tau^{\prime}}-\frac{1}{\tau^{\prime}}\right) t_{0}}=2 \\
& \frac{1}{\tau_{1}}=\frac{\alpha_{1}}{\tau_{1}} \\
& \frac{1}{\tau_{2}^{\prime}}=\frac{\alpha_{2}}{\tau_{2}}
\end{aligned}
$$

The goal of this analysis is to find the ratio $\tau_{2} / \tau_{1}$. Taking into account dependence of $n_{i}$ obtained by direct summations of the respective $n_{i}$ rows, where values of $q_{i}$ are defined in (2) and further fitting both cases with $q_{1}=0.206$ and $q_{2}=0.190$ by exponential function ( 2 ), we found that $\alpha_{1} \approx 0.190$ and $\alpha_{2} \approx 0.198$.

Since Equation (3) consists of two unknown parameters, we carried out numerical analysis of the $\tau_{2} / \tau_{1}$ dependence on $\tau_{1}$, where $t_{0}$ is a constant with a value set at 10 days. Taking into account Equation (3) we carried out numerical analysis, the results of which are shown in Figure 3.

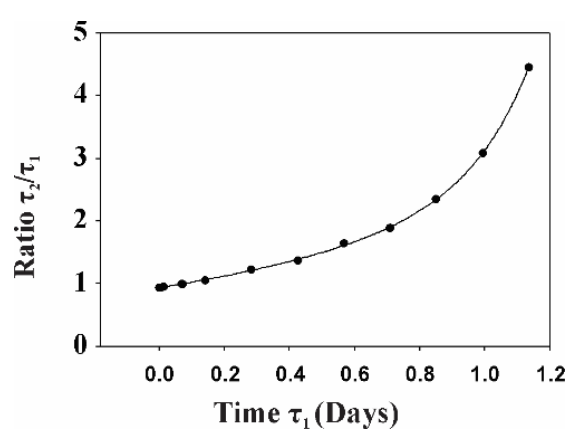

Figure 3. The dependence of $\tau_{2} / \tau_{1}$ on $\tau_{1}$, where $t_{0}$ is constant and equal to 10 days.

As can be seen from this figure, if $\tau_{2} / \tau_{1}$ decreases, the ratio asymptotically approaches the 0.94 limit, while if $\tau_{1}$ increases, the ratio increases nonlinearly. Since the value of $\tau_{1}$ is unknown, we can make only a qualitative conclusion that the duplication time of untreated cells is larger than the time for gp120-treated cells for $\tau_{1}>0.19$ days. If $\tau_{1}=0.19$ days, a ratio of treated versus untreated cells of 2 is obtained at approximately 78 duplication cycles. For a culture containing an average of $20 \%$ of the cells in the G2/M phase, this results in $78 \times 0.20=16$ duplication events for each cell in the culture. Taking into account that, on average, $10 \%$ of the cells in the culture undergo apoptosis (Figure 1B), this number of duplication events corresponds to the average number of duplication cycles for glioma cells cultured for 10 days and confirms that a 1.6\% difference in the percentage of cells in the G2/M phase between the groups provides a two-fold differences in the total number of cells at 10 days. 
2.2. Gp120 Causes Upregulation in the Expression of Glycolytic Enzymes and Increases the Ratio of Glycolytic Index in Glioma Cells

As we recently published, quantitative Tandem Mass Tag (TMT) isobaric labeling quantitative proteomics analysis revealed that gp120 causes upregulation of a number of proteins involved in glycolysis and in the tricarboxylic acid (TCA) cycle in glioma cells including enolase 2 (ENO2), glyceraldehyde-3-phosphate dehydrogenase (GAPDH) and malate dehydrogenase [32].

In order to characterize the mechanisms underlying the increased proliferation of glioma cells treated with gp120, we validated expression levels of glycolytic enzymes by immunoblotting. A significant increase in protein expression was observed for hexokinase (HXK), ENO2 and GAPDH in all the glioma cell lines tested (Figure 4). At the same time, we observed increased activity of HXK and GAPDH (Figure 5). No elevation of pyruvate kinase M (PKM2) expression was observed. Detection of endogenous levels of total PKM protein (including M1 and M2) also did not identify any significant difference between gp120 treated and untreated glioma cells (Supplemental Figure S4). However, colorimetric pyruvate kinase activity assays revealed a significant increase in pyruvate production in cells treated with gp120 for 7-10 days compared to untreated cells (Figure 5), indicating an increase in PKM2 enzymatic activity. This effect was not observed at a shorter time points of gp120 treatment (Supplemental Figure S1B). These findings indicate that the HIV glycoprotein gp120 increases the enzymatic activity of PKM2 in glioma cells without affecting total PKM2 protein levels.

Apoptosis inducers dexamethasone, temozolomide and puromycin were used to control the activity of glycolytic enzymes in glioma cells after apoptosis was induced (Supplemental Figure S5). Data demonstrate that after exposure to inducers of apoptosis, cells exhibited no significant increase in the activity of glycolytic enzymes, indicating that observed gp120-relatad activation of glycolytic enzymes is not associated with the apoptosis mechanism.

Despite the increase in protein expression for ENO2 and GAPDH, we did not observe a significant increase in the mRNA level of these enzymes. In the case of HXK, similar to the up regulation in protein levels, we observed an increase in HXK mRNA (Supplemental Figure S6), suggesting that gp120-induced expression of specific glycolytic enzymes in glioma cells can be regulated at both the transcriptional and translational levels.

A

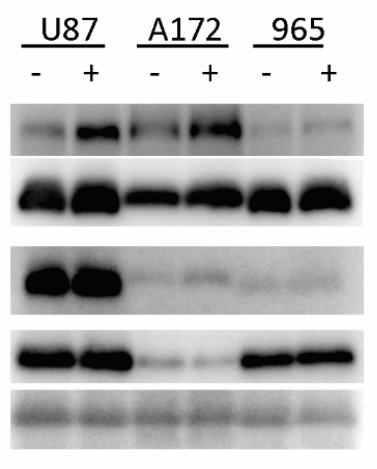

B

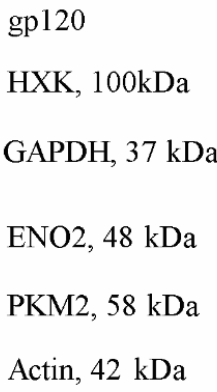

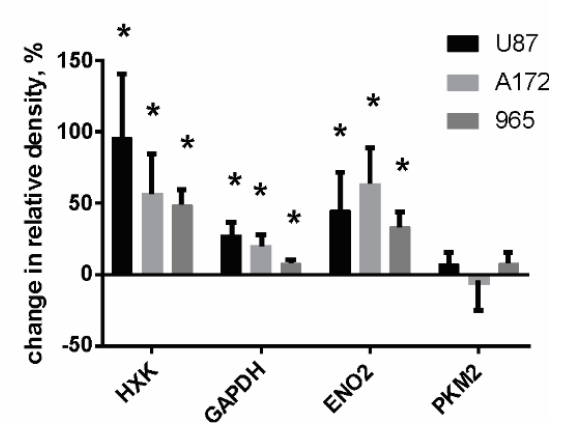

Figure 4. Gp120 upregulates expression of glycolytic enzymes in glioma cells. Western blot (A) and quantification of relative changes of glycolytic enzyme protein levels (B) for untreated and gp120-treated glioma cells. The bar graph shows the percent change in density of protein in gp120-treated relative to untreated cells. U87 and A172 cell lines and 965 primary glioma cells were investigated. $\beta$-actin was used as a loading control. The intensity of the chemiluminescent signal was corrected for minor changes in protein content after densitometry analysis of the India ink-stained membrane. Results are presented as mean \pm S.D. with significant differences from control $\left(^{*}\right)(p<0.05)$. An unpaired $t$-test was used to determine the significance between gp120-treated and untreated groups. Five independent experiments $(n=5)$ for each cell line were used for statistical analysis. 

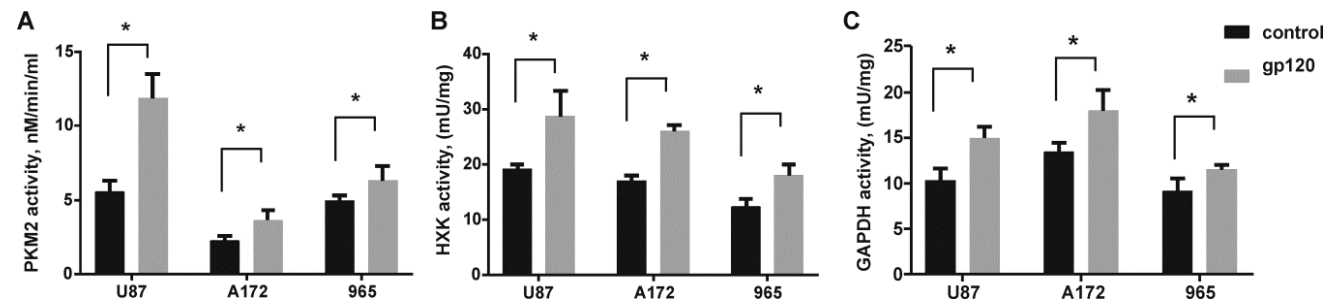

Figure 5. Gp120 increases the activity of glycolytic enzymes in glioma cells. Colorimetric/fluorometric pyruvate kinase (A), hexokinase (B) and glyceraldehyde 3-phosphate dehydrogenase (C) activity assays were performed in untreated U87, A172 and 965 glioma cells and the same cells continuously treated with gp120 for 7-10 days. Kinase activity was calculated as the amount of product (pyruvate, $\mathrm{NADPH}$ and NADH respectively) produced in a sample in $10 \mathrm{~min}$. Mean \pm S.E. and significant differences between control and gp120 treatment $\left.{ }^{*}\right)$ are shown $(p<0.05)$. Unpaired $t$-tests were used to determine the significance between groups. Five independent experiments $(n=5)$ were used for statistical analysis.

To estimate the glycolytic activity in gp120 treated and untreated glioma cells we performed a combination of assays including glucose uptake assay, fluorometric oxygen consumption assays, glycolysis (extracellular acidification) assays and ATP production colorimetric assays. In all cell lines studies, we observed a significant increase in the glucose uptake ratio in gp120-treated versus untreated cells (Figure 6). Treatment with gp120 resulted in a 1.5 times increase in glucose uptake in U87 cells, 2.7 times increase in A172 cells and 2 times increase in 965 cells. Additionally, the study revealed a strong increase in glycolysis (extracellular acidification) of 50 to $200 \%$ in response to $7-10$ days gp120 treatment in the three glioma cell lines tested, with the highest increase observed in U87 cells (200\%) and the smallest response in 965 cells (50\%) (Figure 7A). Similarly, gp120 treatment resulted in 6-10\% increase in oxygen consumption and ATP production, indicating that oxidative phosphorylation is also affected by gp120 in glioma cells, although to a lower extent than the glycolytic pathway. By calculating the ratio of glycolytic indexes (lactate generation rate $\times$ glucose uptake rate)/oxygen consumption rate) we revealed a 10-15 times increase in treated glioma cells (Figure 7B), indicating a glycolytic shift in response to gp120.

A

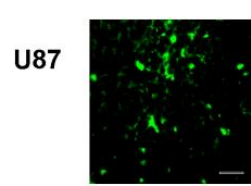

A172
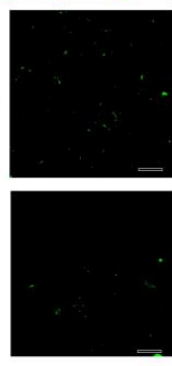

fluorescence
Control
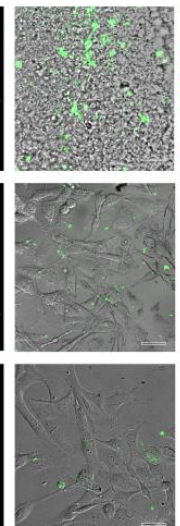

bright field composite gp 120
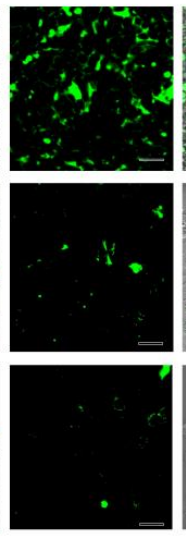

fluorescence

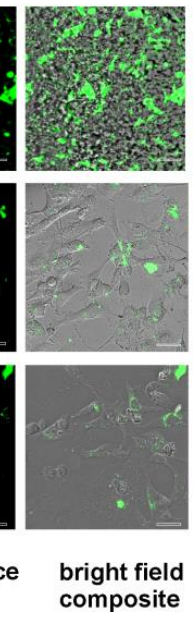

B

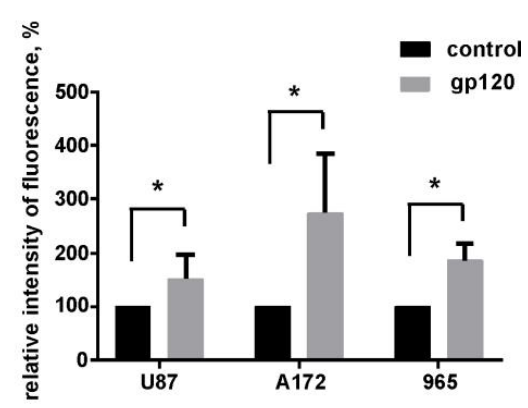

Figure 6. Gp120 increases glucose uptake in glioma cells. Glucose uptake assays were performed for untreated and gp120 treated for 7-10 days U87, A172 and 965 glioma cells. Confocal images showing the uptake of GluTracker reagent in the cytoplasm (A) and quantification of relative fluorescence intensity (B) are presented. Mean \pm S.E. and significant differences between control and gp120 treatment $\left(^{*}\right)$ are shown $(p<0.05)$. Unpaired $t$-tests were used to determine the significance between groups. Five independent experiments $(n=5)$ were used for statistical analysis. Scale bar: $20 \mu \mathrm{m}$. 

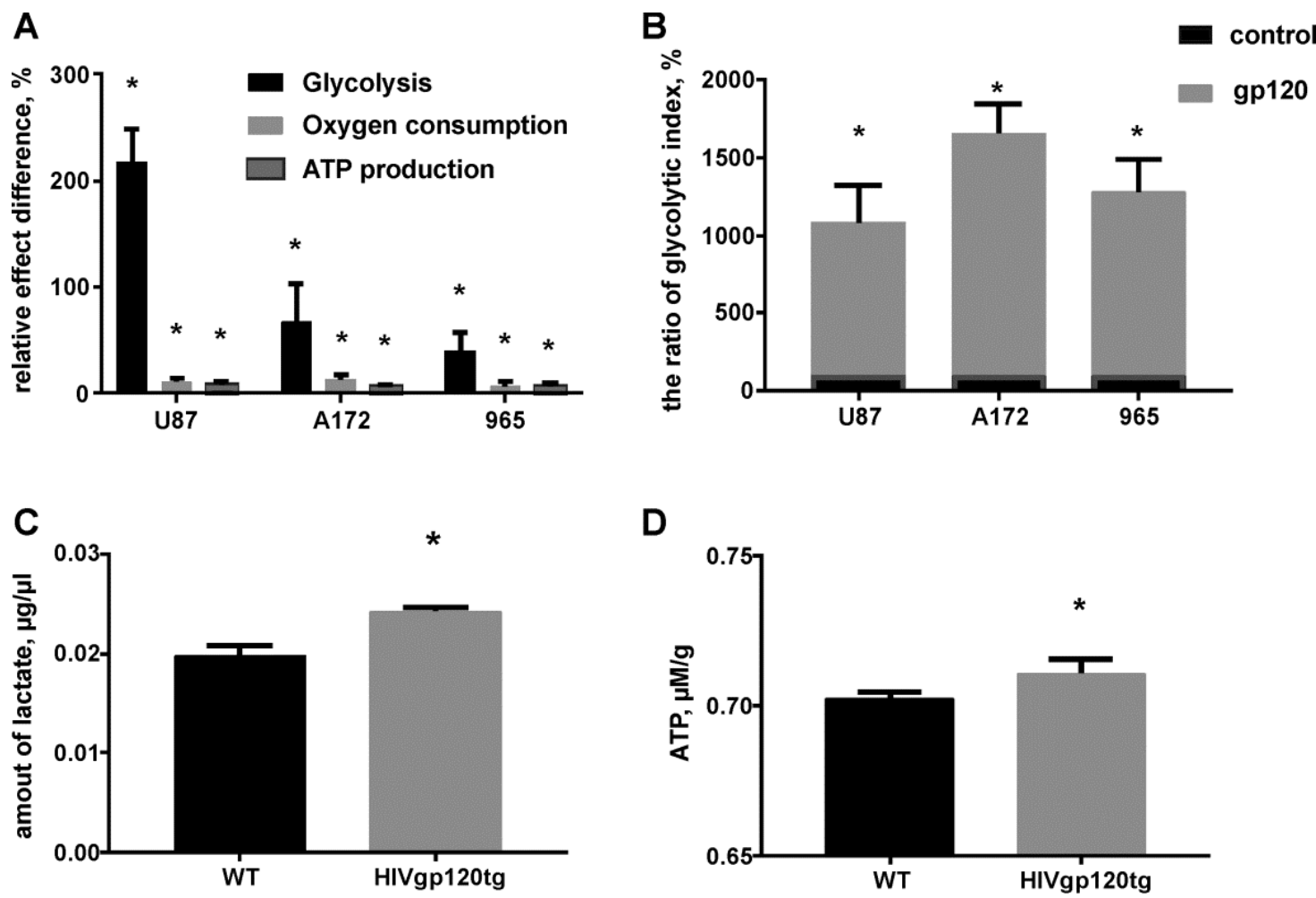

Figure 7. Gp120 causes a glycolytic shift in glioma cells. (A) Colorimetric/fluorometric assays were performed for multiplex detection of extracellular acidification, extracellular oxygen consumption and ATP production in U87, A172 and 965 glioma cells. (B) Quantification of intracellular rates of glycolytic index using extracellular acidification, oxygen consumption and glucose uptake measurements. Data presented as a percent deviation from the control. (C,D) Colorimetric assays were performed for detection of lactate (C) and ATP (D) in tumors generated in WT and HIVgp120tg mice by in-brain implantation of Gl261 cells. Mean \pm S.E. and significant differences between control and gp120 treatment $\left(^{*}\right)$ are shown $(p<0.05)$. Unpaired $t$-tests were used to determine the significance between groups. Five independent experiments $(n=5)$ were used for statistical analysis.

Finally, we analyzed lactate and ATP production in glioma tumors generated in HIVgp120tg and WT mice. Similar to our results in glioma cell lines, we detected a significant increase in lactate production $(21 \%)$ and a $2 \%$ increase in ATP production in tumor tissues extracted from the brains of HIVgp120tg animals (Figure 7C,D).

\subsection{Inhibition of Glycolysis Eliminates the Stimulatory Effect of gp120 on Glioma Cell Growth}

To investigate whether the increased proliferation we observed in glioma cells in response to gp120 was dependent on glycolysis we investigated the effect of sodium monofluorophosphate (FP), a competitive blocker of ENO2 and glycolysis, on glioma cell viability. Cytotoxic effect of FP on gp120-exposed and unexposed glioma cells was investigated in dose-response study with use of cell cycle analysis and trypan blue staining of dead cells (Supplemental Figure S7A,B). Treating glioma cells with a low $(0.9 \mathrm{~mm} / \mathrm{mL})$ and a high $(3.0 \mathrm{mg} / \mathrm{mL})$ dose of FP resulted in an increased number of cells in G1 and a lower number of cells in the S phase. At $0.9 \mathrm{mg} / \mathrm{mL}$ FP the treatment resulted in a significant reduction of cells in the G2/M phase which correlates with a reduction in the $S$ phase and the increase in G1. At the higher dose of $3 \mathrm{mg} / \mathrm{mL}$, FP treatment increased the G2/M fraction indicating a cell cycle arrest. Based on these results, we selected the lower concentration of FP for further experiments as it showed no toxic effects while still capable of reducing PMK2 activity to control levels in cells treated with gp120 (Supplemental Figure S7C). 
When glioma cells grown in medium supplemented with gp120 were treated with FP, the effect of increased viability observed in response to gp120 was reversed (Figure $8 \mathrm{~A}$ ). Because we did not observe significant cell death in response to FP treatment (Figure 8B), detected viability can be interpreted solely as a result of proliferation. This conclusion is confirmed by cell cycle analysis of gp120-treated and untreated glioma cells in the presence or absence of FP $(0.9 \mathrm{mg} / \mathrm{mL})$ (Supplemental Figure S7D). In gp120-exposed glioma cells treated with FP the cell cycle activity was partially reversed till the control level compare to gp120-unexposed cells treated with FP.
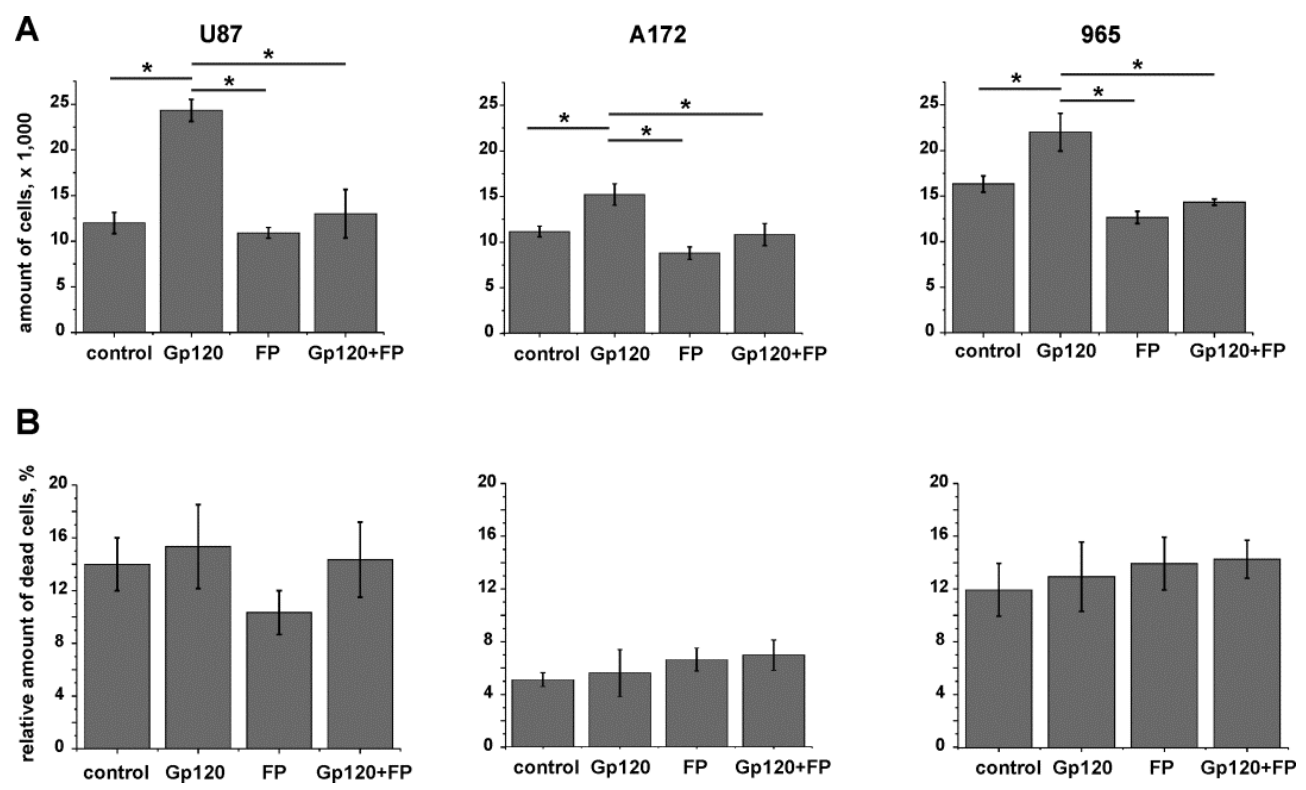

Figure 8. Sodium monofluorophosphate (FP) reverses the effect of gp120-induced proliferation in glioma cells. Experiments were performed in untreated glioma cells and cells continuously treated with gp120 for 10 days. U87 and A172 cell lines and 965 primary glioma cells were investigated. Cells were treated with FP, $0.9 \mathrm{mg} / \mathrm{mL}$, for $24 \mathrm{~h}$ and live and dead cells were counted with the use of trypan blue staining. (A) Cell viability was evaluated as the total number of live cells grown in $24 \mathrm{~h}$. (B) The proportion of dead cells was evaluated as the percentage of the total number of cells. Mean \pm S.E. and significant differences from control $\left({ }^{*}\right)$ are shown $(p<0.05)$. Unpaired $t$-tests were used to determine the significance between groups. Six independent experiments $(n=6)$ were used for statistical analysis.

\section{4. gp120 Causes Stimulation of Protein and Lipid Synthesis and a Reduction of Protein Degradation}

In order to evaluate the metabolic pathways affected in glioma cells in response to gp120 we performed a metabolomic analysis. All metabolites differentially expressed in gp120 treated and untreated U87 cells are presented in Table 1.

These results revealed a significant reduction in the number of essential and nonessential amino acids, including valine, leucine, isoleucine, alanine and glycine in cells treated with gp120. Additionally, we observed a non-significant downregulation of tyrosine, cysteine and aspartate. Accordingly, canonical pathways identified by Ingenuity pathway analysis (IPA) predicted significant changes in aminoacyl-tRNA biosynthesis ( $p$ value $=8.56 \mathrm{E}-38$ ). At the same time, a six-fold reduction in urea, the principal end product of protein catabolism, was observed. Thus, downregulation of these amino acids together with the reduction in urea levels predicts the activation of protein synthesis and reduction of protein degradation. 
Table 1. Metabolite compounds that were deregulated in gp120-treated U87 glioma cells compared to untreated cells according to GCMS/MS metabolomics analysis. * Cells were treated with gp120 for 10 days. Compounds highlighted in bold have values that are significantly different from the untreated group $(p<0.05)$.

\begin{tabular}{|c|c|c|c|c|c|c|}
\hline ID HMDB & Compound ID & $\begin{array}{c}\text { Retention } \\
\text { Time } \\
\text { (min) }\end{array}$ & $\begin{array}{l}\text { Fold } \\
\text { Change }\end{array}$ & $\begin{array}{l}p \text { Value } \\
(t \text { Test })\end{array}$ & $\begin{array}{l}\text { Characteristic } \\
\text { Fragment Ions }\end{array}$ & $\begin{array}{l}\text { Up/Down } \\
\text { Regulation }\end{array}$ \\
\hline MDB00190 & L-lactic acid & 10.27 & 1.612 & $2.50 \mathrm{E}-01$ & $73,147,261$ & + \\
\hline HMDB00161 & L-alanine & 10.99 & 0.223 & $1.90 \mathrm{E}-02$ & $73,158,232$ & - \\
\hline HMDB00123 & glycine & 11.30 & 0.281 & 3.37E-02 & $73,147,218$ & - \\
\hline HMDB00294 & UREA & 12.60 & 0.165 & $9.25 \mathrm{E}-05$ & $104,147,231$ & - \\
\hline HMDB00883 & L-valine & 12.72 & 0.357 & $4.53 \mathrm{E}-02$ & $73,186,260$ & - \\
\hline HMDB00687 & L-leucine & 13.29 & 0.236 & 1.32E-02 & $73,200,274$ & - \\
\hline HMDB00172 & L-isoleucine & 13.74 & 0.013 & $1.29 \mathrm{E}-02$ & $73,200,274$ & - \\
\hline HMDB00162 & L-proline & 14.25 & 23.786 & 2.70E-02 & $73,184,258$ & + \\
\hline HMDB00267 & 5-oxoproline & 16.61 & 2.243 & $1.41 \mathrm{E}-02$ & $73,272,300$ & + \\
\hline HMDB00696 & L-methionine & 16.83 & 2.094 & 2.42E-02 & $73,218,292$ & + \\
\hline HMDB00187 & L-serine & 17.11 & 3.14 & 2.59E-03 & $73,288,390$ & + \\
\hline HMDB00812 & $\mathrm{N}$-acetyl-L-aspartic acid & 17.30 & 0.728 & 7.33E-01 & 73,346 & - \\
\hline HMDB00167 & L-Threonine & 17.51 & 0.993 & $6.35 \mathrm{E}-01$ & $73,303,404$ & - \\
\hline HMDB00806 & Myristic acid & 18.18 & 4.479 & $2.25 \mathrm{E}-01$ & 75,285 & + \\
\hline HMDB00159 & L-phenylalanine & 18.32 & 0.899 & 9.85E-01 & $73,234,302$ & - \\
\hline HMDB00254 & Succinic acid & 14.1 & 1.723 & 2.92E-01 & $73,147,289$ & + \\
\hline HMDB00156 & Malic acid & 18.53 & 1.73 & 0.28091 & $73,115,419$ & + \\
\hline HMDB00191 & L-aspartic acid & 19.03 & 0.783 & 2.63E-01 & $73,302,418$ & - \\
\hline HMDB00574 & L-cysteine & 19.62 & 0.633 & $1.84 \mathrm{E}-01$ & $73,378,406$ & - \\
\hline HMDB03229 & Palmitoleic acid & 20.16 & 3.205 & $1.85 \mathrm{E}-02$ & $75,129,311$ & + \\
\hline HMDB00123 & L-glutamic acid & 20.33 & 2.501 & $4.10 \mathrm{E}-02$ & $73,272,432$ & + \\
\hline HMDB00220 & Palmitic acid & 20.43 & 1.093 & 8.04E-01 & $75,129,313$ & + \\
\hline HMDB00641 & L-glutamine & 21.91 & 1.05 & $6.64 \mathrm{E}-01$ & $73,147,431$ & + \\
\hline HMDB00207 & Oleic acid & 22.27 & 4.44 & 4.41E-02 & $75,129,339$ & + \\
\hline HMDB00827 & Stearic acid & 22.50 & 3.63 & 3.28E-03 & $75,129,341$ & + \\
\hline HMDB00094 & Citric acid & 23.84 & 1.506 & $5.22 \mathrm{E}-01$ & $73,459,591$ & + \\
\hline HMDB00158 & L-tyrosine & 24.05 & 0.846 & 9.93E-01 & 73,302 & - \\
\hline HMDB00929 & L-tryptophan & 24.49 & 15.672 & 1.81E-03 & $73,302,375$ & + \\
\hline HMDB01874 & Isocitric acid & 24.60 & 0.312 & 7.72E-01 & 73,345 & - \\
\hline HMDB00067 & Cholesterol & 37.20 & 1.010 & 4.59E-01 & 75,443 & + \\
\hline
\end{tabular}

Additionally, we discovered an increase in serine ( 3.14 fold), glutamate ( 2.5 fold) and methionine ( 2.1 fold) in gp120-treated cells as well as a drastic increase in proline ( 23.7 fold) and tryptophan (15.6 fold). Since the biosynthesis of serine starts with 3-phosphoglycerate, an intermediate metabolite from glycolysis produced by GAPDH, which we previously observed to be upregulated in response to gp120, we conclude that gp120 stimulates the serine metabolic pathway through the stimulation of glycolysis, which was predicted to be significantly increased according to IPA canonical pathway analysis ( $p$ value $=6.04 \mathrm{E}-07$ ) due to enhanced expression of ENO2, GAPDH and PKM2 (Figure 9). The elevation of lactate observed in gp120-treated cells also indicates an intensification of glycolysis and supports our conclusion.

Upregulation of 5-oxoproline together with a 3-fold reduction in glycine in gp120-treated cells was induced by activation of the $\gamma$-glutamyl cycle, which was predicted to be significantly shifted to the production of 5-oxoproline according to IPA canonical pathway analysis ( $p$ value $=1.44 \mathrm{E}-07)$. This finding is consistent with reports indicating that the deficit of glycine results in a metabolic switch in the $\gamma$-glutamyl cycle resulting in the production of 5-oxoproline but not glutathione [38,39]. Upregulation of glutamate together with proline indicates formation of a 5-oxoproline-glutamate-proline metabolic axis (Figure 9). 


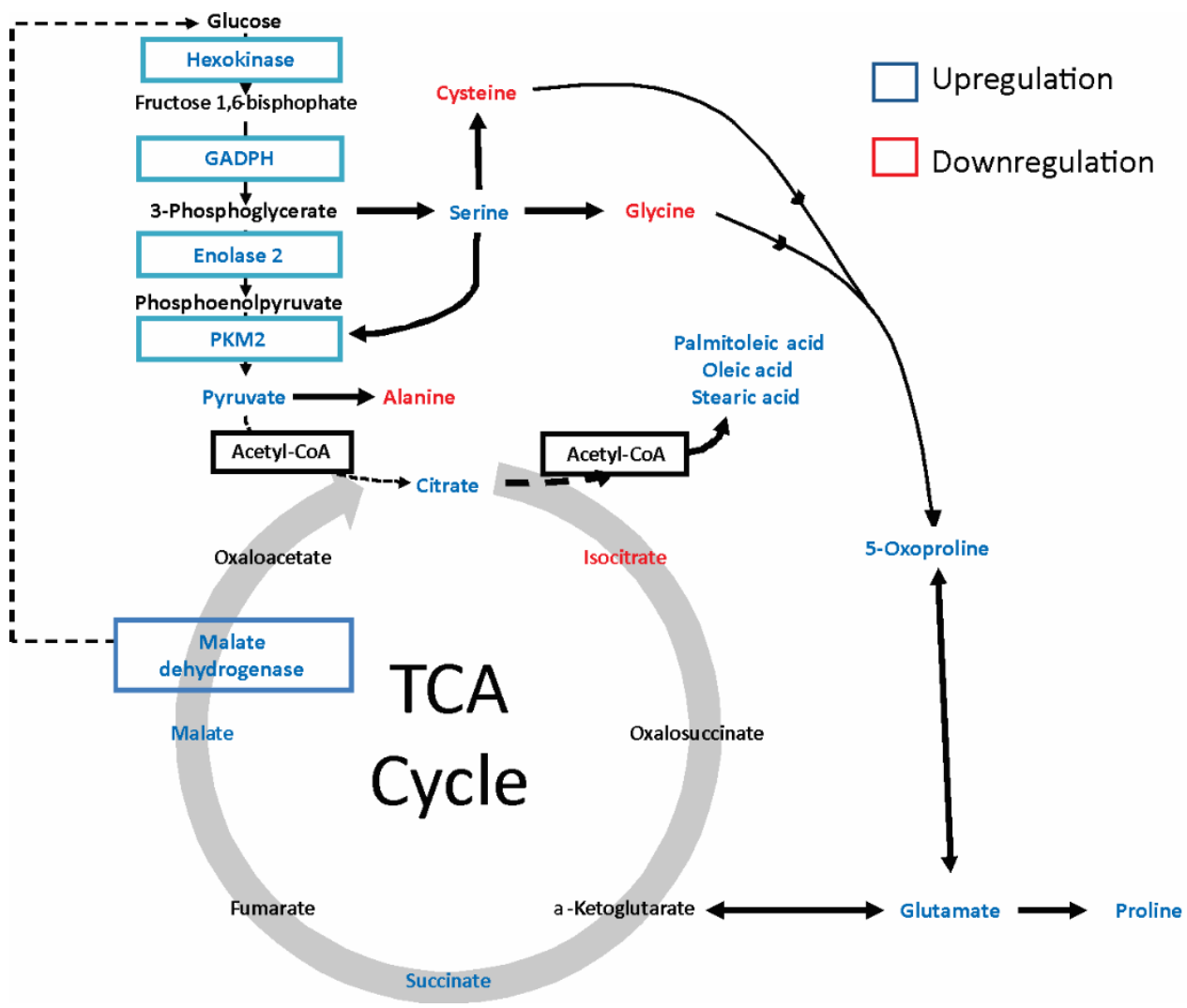

Figure 9. Schematic representation of the metabolic pathways altered in glioma cells by gp120 protein.

The IPA canonical pathway analysis also predicted a significant increase in TCA cycle turnover ( $p$ value $=4.2 \mathrm{E}-05)$ as revealed by the upregulation of its metabolic intermediates including citrate, succinate, and malate. Concomitant with these results, isocitrate was downregulated, suggesting an increase in fatty acid synthesis (see below). These results correlate with our data from oxygen consumption and ATP production assays and strongly support our conclusion that oxidative phosphorylation is increased in glioma cells in response to gp120.

U87 glioma cells treated with gp120 showed an upregulation of stearic, oleic, myristic and palmitoliec fatty acids. Considering that citrate is the primary substrate for the fatty acid synthesis pathway [40], the observed upregulation of citrate together with reduction of isocitrate and upregulation of fatty acids indicates the activation of fatty acid synthesis metabolism and the use of citrate for fatty acid synthesis in glioma cells in response to gp120.

The reduction of isocitrate was followed by upregulation of succinate and malate. The fact that glutamate was upregulated in gp120-treated cells, glutamate dehydrogenization and conversion to $\alpha$-ketoglutarate with further entry into the TCA cycle is plausible and would explain the upregulation of downstream TCA cycle metabolites, such as succinate and malate.

To further confirm our data on metabolomics analysis and the predicted increase in protein synthesis in glioma cells in response to gp120 treatment we analyzed global protein synthesis by flow cytometry using an assay based on O-Propargyl-puromycin and further staining of truncated polypeptides with a fluorescent azide. Therefore, an increase in fluorescence detected by Flow Cytometry indicates an increase in global protein synthesis.

Our results showed an increase in the fluorescence of U87, A172 and 965 glioma cell lines treated with gp120 for 7-10 days compared to untreated cells further confirming that in these cells, protein synthesis is increased in response to gp120 (Figure 10). Taken together with our data on metabolomics, amino acids composition and urea production, these results indicate that treatment with gp120 results in a strong activation of protein synthesis in glioma cells. 
A

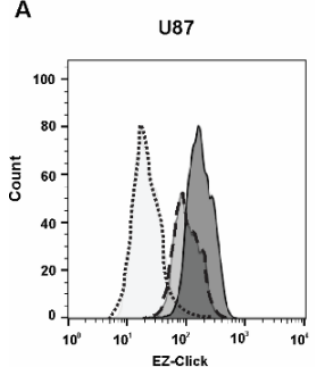

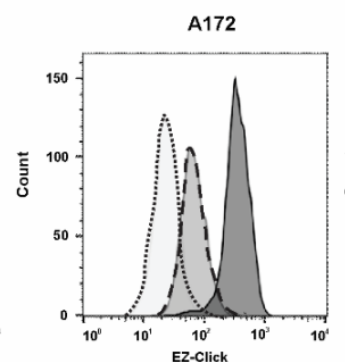

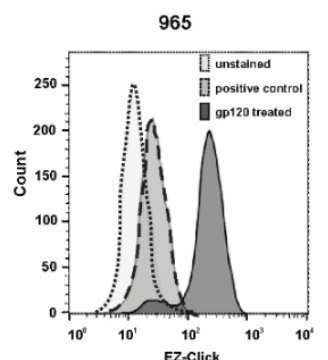

B

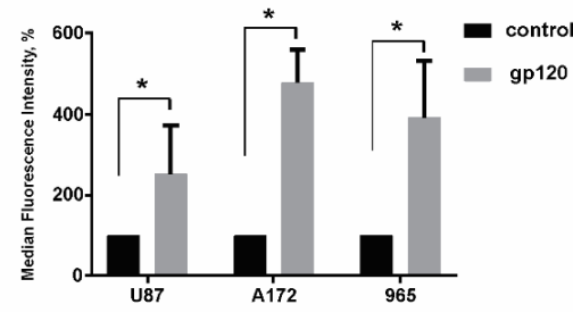

Figure 10. Gp120 increases global protein synthesis in glioma cells. EZClick Global Protein Synthesis Assay Kit (BioVision Inc, Milpitas, CA, USA), followed by flow cytometry analysis, was used for the identification of de novo synthesis of polypeptides. Experiments were performed for untreated glioma cells and cells continuously treated with gp120 for 7-10 days. U87 and A172 cell lines and 965 primary glioma cells were investigated. (A) Graphs represent the total distribution of stained cells in gp-120 treated and untreated glioma cell lines. (B) The relative median fluorescence intensity is calculated as a percentage of median fluorescence intensity in cells treated with gp120 relative to untreated cells. Mean \pm S.E. and significant differences between gp120-treated and untreated groups $\left(^{*}\right)$ are shown $(p<0.05)$. Unpaired $t$-tests were used to determine the significance between groups. Four repeated experiments $(n=4)$ were used for statistical analysis.

\section{Discussion}

Our study demonstrated that the HIV glycoprotein gp120 promotes proliferation, migration, survival and stimulates glycolysis in glioma cell lines. Increased glycolysis, also known as the Warburg effect, is characteristic of malignancy [41,42]. Upregulated glycolysis promotes unconstrained proliferation and invasion of tumor cells, providing the required glycolytic intermediary precursors for DNA, protein and lipid synthesis [43]. In Figure 9 we summarized the metabolic pathways that are altered in glioma cells in response to gp120. We observed an upregulation of the key glycolytic enzymes HXK, GAPDH and ENO2 in glioma cells treated with gp120. Despite the fact that we did not observe an upregulation of PKM2 protein levels-the enzyme that catalyzes the final step of glycolysis, converting phosphoenolpyruvate (PEP) to pyruvate-we found a significant increase in PKM2 activity and pyruvate synthesis, as well as an increase in the glycolytic index. These findings indicate that gp120 stimulates the glycolytic pathway in glioma cells.

HIV infects immune cells by binding to CD4, CCR5 and CXCR4 through its envelope protein gp120 [44-47]. Current evidence suggests that most, if not all, GBMs express CXCR4 and CCR5 [27-29] and these receptors are related to the survival, invasiveness, proliferation and resistance to the radioand chemotherapy of glioma tumors [27,28,30,48-50]. It has been shown that activation of CCR5 and CXCR4 promotes a global shift towards anabolic metabolism and increased cell proliferation: increased glucose uptake, ATP production and enhanced glycolysis, associated with extracellular acidification [51-53]. Numerous viruses have been shown to cause significant alterations in the metabolism of the host cell, including HIV, hepatitis C, influenza, herpes simplex and human cytomegalovirus [54]. The production of the enveloped viruses requires additional fatty acid and nucleotide synthesis to progeny virions and these biosynthetic pathways are supported by the upregulation of glycolysis and the TCA cycle in a host cell [55-57]. It was noted that these changes in metabolic activity of infected cell are similar to oncogenic transformation [58,59], suggesting that the biosynthetic needs of a virally infected cell are similar to those of proliferating cells. Based on these reports, we assume that the gp120-induced activation of glycolysis and cell proliferation might result from activation of cell surface signaling molecules, such as CXCR4 or CCR5 and further-downstream signaling activation in glioma cells. It was reported that activation of CXCR4 and CCR5 leads to the activation of AKT [60-62] and promotes tumor proliferation [63]. Activated AKT phosphorylates multiple downstream targets including Glycogen Synthase Kinases (GSK3) and Mammalian Target of Rapamycin (mTOR) involved in glycogen metabolism, glucose homeostasis and protein synthesis 
regulation $[64,65]$. GSK3 is over activated in GBMs and the level of GSK3 phosphorylation is associated with increased tumor growth [66,67]. It is plausible that gp120 binding to CXCR4 and CCR5 activates AKT/GSK3 signaling resulting in upregulation of glycolysis in glioma cells. Reported downregulation of Phosphatase and Tensin Homolog (PTEN) in investigated glioma cell lines [68-70], upregulation of AKT signaling and high level of activity of GSK3, might provide the mechanistic ground for gp120-driven proliferation and metabolic switch specifically in gliomas but not in other investigated cancer cell lines. However, the detailed evaluation of underlying signaling mechanism is a subject for future studies.

PKM2, which we found to be activated in response to gp120 in glioma cells, is another critical player in the metabolic reprogramming of cancer cells. PKM2 can be translocated into the nucleus and induce cellular proliferation [71] and has been shown to be activated in cancerous tissues [72,73]. PKM2 is found as dimeric and tetrameric forms in which the tetramer has a high affinity and the dimer has a low affinity for phosphoenolpyruvate (PEP) [74]. Cancer cells preferentially express the less active form of PKM2 [75,76], leading to accumulation of glycolytic intermediates in upstream pathways and facilitating the formation of cell-building components. The dimer/tetramer ratio acts as a sensor that regulates metabolic synthesis and energy production from mitochondria [76]. Since our study revealed an increase in PKM2 activity in gp120-treated glioma cells without upregulation of the PKM2 protein, we propose that gp120 can affect the PKM2 dimer/tetramer ratio for the coordination of glycolysis with the cell cycle. This conclusion is supported by literature reports indicating that both fructose 1,6-bisphosphate and PEP, the product metabolites of HXK and ENO2, upregulated by gp120 in our study, promote reassociation of the dimer into a tetramer $[77,78]$ and facilitate entry into the Krebs cycle and a decrease in lactate production. This is consistent with our results indicating activation of pyruvate kinase together with an insignificant increase in lactate.

Additionally, it has been shown that serine can bind to and activate PKM2 [79]. Our study established that there is an increase in serine in gp120-treated glioma cells (Table 1). Taken together with the increased in pyruvate kinase activity in these cells, we propose the existence of a serine activation loop in the glycolysis pathway (Figure 9). The biosynthesis of serine starts with the oxidation of 3-phosphoglycerate, the metabolite produced by GAPDH. Upregulation of GAPDH, which we observed in our study, provides 3-phosphoglycerate as a primary source for the serine biosynthesis pathway. In addition to directing activation of PKM2, serine is crucial for cancer growth and oncogenic transformation due to its participation in the biosynthesis of purines, pyrimidines, sphingolipids and several amino acids, including glycine and cysteine [80-83] and has been found to be upregulated in cancers [83].

Our results revealed a reduction in the amino acid levels in cells treated with gp120. Together with the reduction in urea (Table 1) and the upregulation of molecules involved in protein synthesis, previously identified by our group [32], such as the RPS2, RPS13, RPS15 ribosomal proteins and number of initiation and elongation factors as eIF4A1, eIF4G1, PABPC1 and eEFG1, these findings indicate the predominance of anabolic processes over catabolic processes and active protein synthesis. It has been shown that glutamine uptake is essential for growth in a number of cancers [84-89]. Glutamine, through glutamate, is a source of $\alpha$-ketoglutarate in the TCA cycle, glutathione in redox homeostasis and citrate by reductive carboxylation to form lipids and glucosamines [90]. Tumor cells tend to have a large pool of glutamate and this pool is maintained by the cell's ability to convert glutamine into glutamate through glutaminases [91]. The upregulated glutamate observed in gp120-treated glioma cells indicates the increased use of TCA cycle metabolites for synthesis of lipids and amino acids and replenishment of the TCA cycle through the glutamate- $\alpha$-ketoglutarate pathway. An increase in glutamate in gp120-treated cells can result from the increased uptake of glutamine and further conversion into glutamate, such as through the synthesis from 5-oxoproline, which is also upregulated in gp120-treated cells. Recent studies have shown that 5-oxoproline participates in the regulation of $\mathrm{Na}^{+}$-dependent transport of glutamate $[92,93]$ and may contribute to the increased glutamate uptake by gp120-treated glioma cells. 
We detected a 24-fold increase in proline in gp120-treated cells. Proline can be synthesized from glutamine [94] and the metabolism of proline serves as a source of energy during stress, provides signaling reactive oxygen species for epigenetic reprogramming and regulates redox homeostasis [86]. The critical role of proline biosynthesis in maintaining pyridine nucleotide levels by connecting the proline cycle to glycolysis and to the oxidative arm of the pentose phosphate pathway have also been shown [95]. Proline biosynthesis activity has been associated with tumor cell growth, resistance to oxidative stress and energy production [96,97]. Based on this we can assume, that the increase in proline synthesis in gp120-treated glioma cells might be associated to increased proliferation and survival through reprogramming of the glutamine and pyridine pathways.

Abnormal cellular lipid metabolism also plays an important role in cancer. Fatty acid biosynthesis is restricted to a subset of tissues, including liver, adipose and lactating breast tissues. However, reactivation of lipid biosynthesis has been reported in cancers [98,99] and is associated with cancer growth and invasiveness [100,101]. Fatty acids are the major building blocks for the synthesis of phosphoglycerides and are structural components of biological membranes, contributing to cancer cell proliferation. In our study, we detected the upregulation of stearic, oleic, myristic and palmitoleic fatty acids in glioma cells in response to gp120 which together with our other findings supports the increased proliferation and survival in gp120 treated glioma cells.

Another important finding from this study is related to the substantial 15-fold increase in tryptophan in gp120-treated cells. Many cancers drive tryptophan consumption [102] and it has been shown that the primary product of tryptophan metabolism, kynurenine, is an endogenous ligand for the aryl hydrocarbon receptor, which mediates invasive tumor growth and the evasion of immunity [102-104]. The autocrine binding of kynurenine to the aryl hydrocarbon receptor in cancer cells causes the transcriptional activation of genes related to tumor invasiveness [105]. In patients with cancer, the upregulation of indoleamine 2,3-dioxygenase, an enzyme that generate kynurenine from tryptophan, is associated with a poor prognosis [106]. The increased consumption of tryptophan observed in gp120-treated glioma cells may be related to the increased migration of these cells.

\section{Materials and Methods}

\subsection{Cell Culture}

U87 and A172 human glioma cell lines were obtained from the American Type Culture Collection (Manassas, VA, USA). The GL261 glioma cell line derived from C57BL/ 6 mice was obtained from the NCI (Frederick, MD, USA). The 965 primary human glioma cell line was obtained from a resected GBM tumor mass in the laboratory of Dr. Quinones-Hinojosa, Mayo Clinic. Clinical data for 965 primary cell lines have been described and analyzed in detail previously $[68,107,108]$. Cells were cultured in Dulbecco's modified Eagle medium (DMEM) supplemented with 10\% fetal calf serum and $50 \mathrm{U} / \mathrm{mL}$ penicillin $/ 50 \mu \mathrm{G} / \mathrm{mL}$ streptomycin and maintained in a humidified atmosphere of 5\% CO2/95\% air at $37^{\circ} \mathrm{C}$. Cultures used in this study underwent less than sixteen passages.

\subsection{Animals}

All procedures involving rodents were conducted in accordance with the National Institutes of Health regulations concerning the use and care of experimental animals. All procedures involving animals were approved by Universidad Central del Caribe Institutional Animal Care and Use Committee (protocol \#036-214-14-01-PHA from 4 August 2016). All efforts were made to minimize suffering.

HIVgp120tg mice were kindly provided by Dr. Marcus Kaul (Sanford Burnham Prebys Medical Discovery Institute, San Francisco, CA, USA) [35,36]. C57Bl/6 mice were purchased from the Jackson Laboratory. C57Bl/6 and HIV gp120tg mice were crossbred and animals heterozygous for HIV gp120 and wild type littermates were used as experimental and control groups correspondingly. Genotyping was performed according to the previously published protocols [36]. 


\subsection{Intracranial Implantation of Glioma Cells}

All surgeries were performed under isoflurane anesthesia and all efforts were made to minimize suffering. GL261 glioma cells were implanted into the right cerebral hemisphere of 12-16 week old C57BL/ 6 mice. Implantation was performed according to the protocol that we described earlier [109]. Briefly, mice were anesthetized with isoflurane and a midline incision was made on the scalp. At stereotaxic coordinates of bregma, $2 \mathrm{~mm}$ lateral, $1 \mathrm{~mm}$ caudal and $3 \mathrm{~mm}$ ventral a small burr hole $(0.5 \mathrm{~mm}$ diameter) was drilled on the skull. $1 \mu \mathrm{L}$ of cell suspension $(2 \times 104$ cells $/ \mu \mathrm{L}$ in PBS) was delivered at a depth of $3 \mathrm{~mm}$ over $2 \mathrm{~min}$. Sixteen days following injection, animals were anesthetized with pentobarbital $(50 \mathrm{mg} / \mathrm{kg}$ ) and transcardially perfused with PBS followed by $4 \%$ paraformaldehyde (PFA). Brains were removed and postfixed in $4 \%$ PFA/PBS for $24 \mathrm{~h}$ at $4{ }^{\circ} \mathrm{C}$, followed by $0.15 \mathrm{M}, 0.5 \mathrm{M}$ and $0.8 \mathrm{M}$ sucrose at $4{ }^{\circ} \mathrm{C}$ until fully dehydrated. Brains were then frozen-embedded in Cryo-M-Bed embedding compound (Bright Instrument, Huntingdon, England) and cut using a Vibratome UltraPro 5000 cryostat (American Instrument, Haverhill, MA, USA).

\subsection{Tumor Size Evaluation}

$15 \mu \mathrm{m}$ coronal frozen sections encompassing the entire tumor were stained with Hematoxylin \& Eosin. Tumor size was calculated as sum of tumor area $\times$ section thickness for each section containing a tumor.

\subsection{Survival Analysis}

GL261 glioma cells were implanted into HIVgp120tg and WT littermate mice. Animals were inspected daily and body weight loss of $15 \%$, decreased activity/responsiveness, abnormal posture or any neurological disorders signs are to be a subject for euthanasia. Time between tumor bearing and animal death was recorded.

\subsection{In Vitro Viability Assay}

Glioma cells were plated in petri dishes at 200,000 cells per dish and incubated for 10 days with and without gp120 $(100 \mathrm{ng} / \mathrm{mL})$. The cells were then harvested, stained with trypan blue and the total number of live and dead cells determined by cell counting.

\subsection{Migration Assay}

Migration assays were performed using Fluoroblok inserts (8- $\mu \mathrm{M}$ pore size, VWR Scientific). Serum-starved cells $(30,000)$ were placed on the insert membrane and the assays were performed following the addition of medium containing $5 \%$ serum to the lower compartment. After $5 \mathrm{~h}$, the cells were fixed with methanol and stained with propidium iodide. The number of cells that had migrated to the lower compartment was determined by counting the number of fluorescent cells.

\subsection{Cell Cycle Assays}

Cells were harvested, fixed in $70 \%$ ethanol, re-suspended in PBS containing $1 \mu \mathrm{g} / \mathrm{ml}$ 7-AAD (Bio-Rad Laboratories, Hercules, CA, USA) and $0.2 \mathrm{mg} / \mathrm{mL}$ RNase A (Sigma-Aldrich, St. Louis, MO, USA), incubated for $30 \mathrm{~min}$ at $37^{\circ} \mathrm{C}$ in the dark and analyzed with a FACSCanto II flow cytometer (Becton Dickinson, San Jose, CA, USA). The percentage of cells in G0/G1, S and G2/M phases was determined from the DNA content using FlowJo data analysis software v.10 (Ashland, OR, USA).

\subsection{Western Blot Analysis}

Clarified cell lysates separated on 10\% SDS-PAGE gels were transferred to PVDF membranes and probed with mouse anti-ENO2 antibody (Santa Cruz Biotechnology, Dallas, TX, USA; \#SC-21738) and rabbit polyclonal anti-PKM2, anti-GAPDH and anti-HXK antibodies (Cell Signaling, Danvers, MA, USA; \#4053, \#5174 and \#2024, respectively), diluted 1:1000, followed by the secondary 
antibodies (Sigma-Aldrich, Saint Louis, MO, USA; \#A9169). Detection was performed with enhanced chemiluminescence methodology (SuperSignal ${ }^{\circledR}$ West Dura Extended Duration Substrate; Pierce, Rockford, IL, USA) and the intensity of the signal was measured using a gel documentation system (Versa Doc Model 1000, Bio Rad). The intensity of the chemiluminescent signal was corrected for minor changes in protein content after densitometry analysis of the India ink-stained membrane.

\subsection{Pyruvate Kinase, Hexokinase and Glyceraldehyde 3-Phosphate Dehydrogenase Activity Assays}

Intracellular pyruvate, HXK and GAPDH activity was measured in cell lysates with the Pyruvate Kinase Activity Colorimetric/Fluorometric Assay kit (BioVision, Milpitas, CA, \#K709-100), HXK Activity Fluorometric Assay Kit (Abcam, Cambridge, MA, USA, \#ab211103) and GAPDH Activity Colorimetric Assay Kit (Abcam, Cambridge, MA, USA, \#ab204732) according to the manufacturer's protocol. In each experiment, 5,000 cells were used and their OD at $570 \mathrm{~nm}$ (for Pyruvate Kinase Assays), $450 \mathrm{~nm}$ (for GAPDH assays), or fluorescence at Ex/Em = 535/587 nm measured with a Perkin Elmer Wallac 1420 Victor2 Microplate Reader. Standard curves were used to determine the concentration of pyruvate, HXK, or GAPDH in the sample from the numeric colorimetric/fluorometric data. Enzyme's activity was calculated as the amount of product produced in the sample in $10 \mathrm{~min}$.

\subsection{Glucose Uptake Assays}

Glucose uptake was measured with the cell-based Glucose Uptake Assay Kit (Abcam, Cambridge, MA, USA, \#ab204702) according to the manufacturer's protocol. 50,000 cells were seeded on coverslips one day before starting the assay. Cells were incubated with glucose uptake mix containing fluorescent GluTracker reagent for $30 \mathrm{~min}$ and immediately visualized using an Olympus Fluoview FV1000 confocal microscope (Olympus, Japan) with $40 \times$ oil immersion objective and FITC excitation-emission filter set (absorption maximum at $494 \mathrm{~nm}$ and emission maximum of $521 \mathrm{~nm}$ ). The fluorescent images were processed using ImageJ software.

\subsection{Glycolysis and Extracellular Oxygen Consumption Assays}

Comparative measurements were taken with Glycolysis Assay (Abcam, Cambridge, MA, USA, \#ab197244) and Extracellular Oxygen Consumption Assay (Abcam, Cambridge, MA, USA, \#ab197243) according to the manufacturer's protocols. Cells were seeded in a 96-well plate at a density of 5000 cells/well. $24 \mathrm{~h}$ later the cell culturing medium was replaced with Glycolysis Assay Reagent or Extracellular Oxygen Consumption Reagent and the assay's signals were measured simultaneously with a Perkin Elmer Wallac 1420 Victor2 Microplate Reader using Ex/Em = 380/615 nm.

\subsection{ATP and Lactate Assays}

ATP and L-Lactate were measured in cell lysates with the ATP Assay Kit (Abcam, Cambridge, MA, USA, \#83355) and L-lactate Assay Kit (Abcam, Cambridge, MA, USA, \#65331) according to the manufacturer's protocol. Cultured cells or tissue lysates were used and their OD at $570 \mathrm{~nm}$ measured with a Perkin Elmer Wallac 1420 Victor2 Microplate Reader. A standard curve was used to determine the concentration of ATP and lactate in the sample from the numeric colorimetric data.

\subsection{Metabolomics Analysis}

Metabolites were extracted using an optimized protocol [110]. Cultured cells were scraped in $\mathrm{MeOH} / \mathrm{H} 2 \mathrm{O}(85: 15)$, sonicated and centrifuged at 13,000× g. The supernatant was dried in a SpeedVac (Savant AS160, Farmingdale, NY, USA), followed by methoxyamination in a $20-\mathrm{mg} / \mathrm{mL}$ methoxyamine hydrochloride in pyridine (Sigma-Aldrich, St. Louis, MO, USA) and trimethylsilylation in N-methyl-N-trimethylsilyl-trifluoroacetamide (MSTFA + 1\% trimethylchlorosilane (TMCS), ThermoFisher Scientific, Waltham, MA, USA). The supernatants were dissolved 3/50 in hexane and applied to a GC-2010 gas chromatograph (Shimadzu Scientific, Columbia, MD, USA) with an AOC-20i 
auto-injector in split mode (split ratio, 15). The analytes were fractionated on a fused-silica capillary RXI-5MS column (0.25 mm inner diameter, $0.25 \mu \mathrm{m}$ D.F.; $30 \mathrm{~m}$; Restek Bellefonte, PA, USA). The oven temperature was set to increase from $100{ }^{\circ} \mathrm{C}$ to $290{ }^{\circ} \mathrm{C}$ at $8{ }^{\circ} \mathrm{C} / \mathrm{min}$. Mass spectra were obtained on a Shimadzu GCMS-QP2010 mass spectrometer (EI, $70 \mathrm{eV}$, ion source temperature, $200{ }^{\circ} \mathrm{C}$ ) in scan mode between 35 and $700 \mathrm{amu}$. The data obtained were processed using GCMS Solution Post-run Analysis software (Shimadzu Corp) for metabolite identification by comparison with the NIST08 spectral mass library (National Institute of Standards and Technology, Gaithersburg, MD, USA) using the NIST MS Search Program 2.0, mass spectral databases and AMDIS Version 2.71 deconvolution software (Automated Mass Spectral Deconvolution and Identification System, www.amdis.net) [111]. Peaks were integrated (maximum peak number, 200; width time, 2 s; smoothing method, standard) and manually checked. The peak intensities were quantified as the fold-change relative to control and the statistical significances were analyzed using Student's $t$-test. $p$-values $<0.05$ were considered significant. Metabolomics analysis was conducted using the IPA core analysis of metabolites (QIAGEN, Redwood City, CA, USA). Data sets containing metabolite identifiers (KEGG IDs) and metabolic enzyme protein identifiers (UNIPROT IDs), including their corresponding fold-change values relative to control, were mapped together with their corresponding objects in the Ingenuity Knowledge. Fisher's exact test was used to calculate the probability that each ID set was enriched. Only the biological functions/pathways (Bonferroni's corrected $p$ value $<0.05$ ) were considered significantly enriched.

\subsection{Protein Synthesis Assay}

EZClick Global Protein Synthesis Assay Kit (BioVision Inc., Milpitas, CA, USA, \#K715-100) was used according to the manufacturer's protocol. Briefly, 500,000 cells were seeded in 60mm petri dishes $24 \mathrm{~h}$ prior to the assay followed by addition of the Protein Label for $1 \mathrm{~h}$. Cells were harvested, fixed and stained with Fluorescent Azide followed by Flow Cytometry analysis, using a BD-FACSCanto II flow cytometer (Becton Dickinson, San Jose, CA, USA). Flow cytometry data was analyzed using FlowJo data analysis software v.10 (Ashland, OR, USA).

\subsection{Chemicals and Reagents}

Sodium monofluorophosphate was obtained from Santa Cruz Biotechnology, Inc., Dallas, TX, USA, cat. \#SC-264320

\subsection{Statistical Analysis}

Results are expressed as mean \pm standard deviation (SD). The statistical probability was calculated using GraphPad software. Unpaired t-tests or one-way ANOVA tests followed by Tukey's post-hoc test were used to determine significance between groups. $p$-values $<0.05$ were considered as significant.

\section{Conclusions}

The HIV envelope protein gp120 stimulates glioma cell growth and glycolytic pathways through upregulation of key glycolytic enzymes, increased pyruvate kinase activity and glucose up-take. In conjunction with increased glycolysis, gp120 stimulates protein and fatty acid synthesis in glioma cells. As a subject for future studies, the signaling pathways initiated by gp120-activated cell surface receptors that may lead to the activation of glycolytic pathways in gliomas should be further investigated as a potential strategy to identify putative drug targets for glioma tumors in HIV infected patients. Additionally, the effect of whole HIV on glioma cell metabolism should be analyzed together with the effect of purified gp120 in vitro and in vivo.

Supplementary Materials: The following are available online at http:/ /www.mdpi.com/2072-6694/10/9/301/s1, Figure S1. Continuous treatment with gp120 increases cell viability and activity of Pyruvate Kinase (PKM2) in U87 cells in 7-10 days; Figure S2. Viability assays were performed for glioma U87 (ATCC, \#HTB-14), prostate PC-3 (ATCC, \#CRL-1435), ovarian UACC-2727 (ATCC, \#CRL-3192), Lewis lung LLC1 (ATCC, \#CRL-1642), and Jurkat T cells (ATCC, \#CRL-2899) tumor cell lines; Figure S3. Immunofluorescent detection of gp120 (green) and 
Glial Fibrillary Acid Protein (GFAP, red) was performed on frozen HIVgp120tg mouse brain sections containing the tumor area; Figure S4. Western blot evaluation of expression levels of Pyruvate Kinase M1/2 (PKM1/2) in U87 glioma cells; Figure S5. Induction of apoptosis is not associated with the activation of glycolytic enzymes in glioma cells; Figure S6. The relative expression of Hexokinase (HXK), Enolase 2 (Eno2) and Glyceraldehyde-3-Phosphate Dehydrogenase (GAPDH) mRNA was detected by qRT-PCR in U87 and A172 glioma cells; Figure S7. Sodium monofluorophosphate (FP) eliminates the stimulatory effect of gp120 in glioma cell proliferation and Pyruvate Kinase (PKM2) activity.

Author Contributions: Acquisition and data analysis from trypan blue, western blot, colorimetric assays, G.V.-G.; cell cycle flow cytometry experiments, S.L.; metabolomics study, N.E.C.; viability assays, J.P.; imaging analysis and presentation, Y.V.K. and M.I.; glioma implantation, J.O.-R.; mathematical support, V.M.; protein synthesis Flow Cytometry data acquisition and analysis, A.V.-A.; development of primary glioma cell line, A.Q.-H.; experimental design, L.K. and N.B. All authors obtained the data, revised the results and helped draft the manuscript.

Funding: This research was funded by NIH grants SC1GM122691 to L.K.; SC2GM111149 to M.I.; 5R25DA030310-05 to N.B, 5P20GM103475 to N.C.; and R01CA183827, R01CA200399, R01CA195503 to A.Q-H.; and by Puerto Rico Science, Technology and Research Trust grant 2016-00157 to Y.K.

Acknowledgments: HIV-1 BaL gp120 recombinant protein (cat. \#4961HIV-1BaL gp120) was obtained through the NIH AIDS Reagent Program, NIAID. HIV gp120tg mice were obtained as a gift from Macus Kaul, Sanford Burnham Prebys Medical Discovery Institute.

Conflicts of Interest: The authors declare no conflict of interest.

\section{References}

1. Frisch, M.; Biggar, R.J.; Engels, E.A.; Goedert, J.J. Association of cancer with AIDS-related immunosuppression in adults. JAMA 2001, 285, 1736-1745. [CrossRef] [PubMed]

2. Hall, J.R.; Short, S.C. Management of glioblastoma multiforme in HIV patients: A case series and review of published studies. Clin. Oncol. (R. Coll. Radiol.) 2009, 21, 591-597. [CrossRef] [PubMed]

3. Chaudhry, N.S.; Ahmad, F.U.; Blieden, C.; Benveniste, R.J. Brainstem anaplastic glioma in patients with AIDS: A case report and review of the literature. BMJ Case Rep. 2013. [CrossRef] [PubMed]

4. Hajjar, M.; Lacoste, D.; Brossard, G.; Morlat, P.; Dupon, M.; Salm, L.; Dabis, F.; Groupe d'Epidémiologie Clinique du SIDA en Aquitaine. Non-acquired immune deficiency syndrome-defining malignancies in a hospital-based cohort of human immunodeficiency virus-infected patients: Bordeaux, France, 1985-1991. J. Natl. Cancer Inst. 1992, 84, 1593-1595. [CrossRef] [PubMed]

5. Blumenthal, D.T.; Raizer, J.J.; Rosenblum, M.K.; Bilsky, M.H.; Hariharan, S.; Abrey, L.E. Primary intracranial neoplasms in patients with HIV. Neurology 1999, 52, 1648-1651. [CrossRef] [PubMed]

6. Moulignier, A.; Mikol, J.; Pialoux, G.; Eliaszewicz, M.; Thurel, C.; Thiebaut, J.B. Cerebral glial tumors and human immunodeficiency virus-1 infection. More than a coincidental association. Cancer 1994, 74, 686-692. [CrossRef]

7. Tacconi, L.; Stapleton, S.; Signorelli, F.; Thomas, D.G. Acquired immune deficiency syndrome (AIDS) and cerebral astrocytoma. Clin. Neurol. Neurosurg. 1996, 98, 149-151. [CrossRef]

8. Choy, W.; Lagman, C.; Lee, S.J.; Bui, T.T.; Safaee, M.; Yang, I. Impact of Human Immunodeficiency Virus in the Pathogenesis and Outcome of Patients with Glioblastoma Multiforme. Brain Tumor Res. Treat 2016, 4, 77-86. [CrossRef] [PubMed]

9. Kasantikul, V.; Kaoroptham, S.; Hanvanich, M. Acquired immunodeficiency syndrome associated with cerebral astrocytoma. Clin. Neuropathol. 1992, 11, 25-27. [PubMed]

10. Acevedo, N.; Pillai, C.; Welch, M. Diagnosis and management of high-grade glioma in patients with HIV. Neuro. Oncol. 2015, 17 (Suppl. 5). [CrossRef]

11. Wiemels, J.L.; Wilson, D.; Patil, C.; Patoka, J.; McCoy, L.; Rice, T.; Schwartzbaum, J.; Heimberger, A.; Sampson, J.H.; Chang, S.; et al. IgE, allergy and risk of glioma: Update from the San Francisco Bay Area Adult Glioma Study in the temozolomide era. Int. J. Cancer 2009, 125, 680-687. [CrossRef] [PubMed]

12. Salvati, M.; Frati, A.; Caroli, E.; Russo, N.; Polli, F.M.; Domenicucci, M.; Delfini, R. Glioblastoma in kidney transplant recipients. Report of five cases. J. Neurooncol. 2003, 63, 33-37. [CrossRef] [PubMed]

13. Chamberlain, M.C. Gliomas in patients with acquired immune deficiency syndrome. Cancer 1994, 74, 1912-1914. [CrossRef] 
14. Wolff, R.; Zimmermann, M.; Marquardt, G.; Lanfermann, H.; Nafe, R.; Seifert, V. Glioblastoma multiforme of the brain stem in a patient with acquired immunodeficiency syndrome. Acta Neurochir. (Wien) 2002, 144. [CrossRef] [PubMed]

15. Simard, E.P.; Pfeiffer, R.M.; Engels, E.A. Cumulative incidence of cancer among individuals with acquired immunodeficiency syndrome in the United States. Cancer 2011, 117, 1089-1096. [CrossRef] [PubMed]

16. Simard, E.P.; Pfeiffer, R.M.; Engels, E.A. Spectrum of cancer risk late after AIDS onset in the United States. Arch. Intern. Med. 2010, 170, 1337-1345. [CrossRef] [PubMed]

17. Silverberg, M.J.; Lau, B.; Achenbach, C.J.; Jing, Y.; Althoff, K.N.; D’Souza, G.; Engels, E.A.; Hessol, N.A.; Brooks, J.T.; Burchell, A.N.; et al. North American AIDS Cohort Collaboration on Research and Design of the International Epidemiologic Databases to Evaluate AIDS. Cumulative Incidence of Cancer among Persons with HIV in North America: A Cohort Study. Ann. Intern. Med. 2015, 163, 507-518. [CrossRef] [PubMed]

18. Hoque, S.A.; Tanaka, A.; Islam, S.; Ahsan, G.U.; Jinno-Oue, A.; Hoshino, H. Suppression of HIV-1 Infectivity by Human Glioma Cells. AIDS Res Hum Retroviruses 2016, 32, 480-488. [CrossRef] [PubMed]

19. Haedicke, J.; Brown, C.; Naghavi, M.H. The brain-specific factor FEZ1 is a determinant of neuronal susceptibility to HIV-1 infection. Proc. Natl. Acad. Sci. USA 2009, 106, 14040-14045. [CrossRef] [PubMed]

20. Petito, C.K. Human immunodeficiency virus type 1 compartmentalization in the central nervous system. J. Neurovirol. 2004, 10 (Suppl. 1), 21-24. [CrossRef]

21. Wesselingh, S.L.; Thompson, K.A. Immunopathogenesis of HIV-associated dementia. Curr. Opin. Neurol. 2001, 14, 375-379. [CrossRef] [PubMed]

22. Ostalecki, C.; Wittki, S.; Lee, J.H.; Geist, M.M.; Tibroni, N.; Harrer, T.; Schuler, G.; Fackler, O.T.; Baur, A.S. HIV Nef- and Notch1-dependent Endocytosis of ADAM17 Induces Vesicular TNF Secretion in Chronic HIV Infection. EBioMedicine 2016, 13, 294-304. [CrossRef] [PubMed]

23. Lipton, S.A. Similarity of neuronal cell injury and death in AIDS dementia and focal cerebral ischemia: Potential treatment with NMDA open-channel blockers and nitric oxide-related species. Brain Pathol. 1996, 6, 507-517. [CrossRef] [PubMed]

24. Li, G.H.; Henderson, L.; Nath, A. Astrocytes as an HIV Reservoir: Mechanism of HIV Infection. Curr. HIV Res. 2016, 14, 373-381. [CrossRef] [PubMed]

25. Power, C.; Gill, M.J.; Johnson, R.T. Progress in clinical neurosciences: The neuropathogenesis of HIV infection: Host-virus interaction and the impact of therapy. Can. J. Neurol. Sci. 2002, 29, 19-32. [CrossRef] [PubMed]

26. Kaul, M.; Zheng, J.; Okamoto, S.; Gendelman, H.E.; Lipton, S.A. HIV-1 infection and AIDS: Consequences for the central nervous system. Cell Death Differ. 2005, 12 (Suppl. 1), 878-892. [CrossRef] [PubMed]

27. Calinescu, A.A.; Yadav, V.N.; Carballo, E.; Kadiyala, P.; Tran, D.; Zamler, D.; Doherty, R.; Srikanth, M.; Lowenstein, P.R.; Castro, M.G. Survival and proliferation of neural progenitor derived glioblastomas under hypoxic stress is controlled by a CXCL12/CXCR4 autocrine positive feedback mechanism. Clin. Cancer Res. 2017, 23, 1250-1262. [CrossRef] [PubMed]

28. Richardson, P.J. CXCR4 and Glioblastoma. Anticancer Agents Med. Chem. 2016, 16, 59-74. [CrossRef] [PubMed]

29. Pham, K.; Luo, D.; Liu, C.; Harrison, J.K. CCL5, CCR1 and CCR5 in murine glioblastoma: Immune cell infiltration and survival rates are not dependent on individual expression of either CCR1 or CCR5. J. Neuroimmunol. 2012, 246, 10-17. [CrossRef] [PubMed]

30. Kouno, J.; Nagai, H.; Nagahata, T.; Onda, M.; Yamaguchi, H.; Adachi, K.; Takahashi, H.; Teramoto, A.; Emi, M. Up-regulation of CC chemokine, CCL3L1 and receptors, CCR3, CCR5 in human glioblastoma that promotes cell growth. J. Neurooncol. 2004, 70, 301-307. [CrossRef] [PubMed]

31. Würth, R.; Bajetto, A.; Harrison, J.K.; Barbieri, F.; Florio, T. CXCL12 modulation of CXCR4 and CXCR7 activity in human glioblastoma stem-like cells and regulation of the tumor microenvironment. Front. Cell Neurosci. 2014, 8, 144. [CrossRef] [PubMed]

32. López, S.N.; Rodríguez-Valentín, M.; Rivera, M.; Rodríguez, M.; Babu, M.; Cubano, L.A.; Xiong, H.; Wang, G.; Kucheryavykh, L.; Boukli, N.M. HIV-1 Gp120 clade B/C induces a GRP78 driven cytoprotective mechanism in astrocytoma. Oncotarget 2017, 8, 68415-68438. [CrossRef] [PubMed]

33. Rychert, J.; Strick, D.; Bazner, S.; Robinson, J.; Rosenberg, E. Detection of HIV gp120 in Plasma During Early HIV Infection Is Associated with Increased Proinflammatory and Immunoregulatory Cytokines. AIDS Res. Hum. Retroviruses 2010, 26, 1139-1145. [CrossRef] [PubMed] 
34. Thaney, V.E.; O’Neill, A.M.; Hoefer, M.M.; Maung, R.; Sanchez, A.B.; Kaul, M. IFN $\beta$ Protects Neurons from Damage in a Murine Model of HIV-1 Associated Brain Injury. Sci. Rep. 2017, 7, 46514. [CrossRef] [PubMed]

35. Maung, R.; Hoefer, M.M.; Sanchez, A.B.; Sejbuk, N.E.; Medders, K.E.; Desai, M.K.; Catalan, I.C.; Dowling, C.C.; de Rozieres, C.M.; Garden, G.A.; et al. CCR5 knockout prevents neuronal injury and behavioral impairment induced in a transgenic mouse model by a CXCR4-using HIV-1 glycoprotein 120. J. Immunol. 2014, 193, 1895-1910. [CrossRef] [PubMed]

36. Toggas, S.M.; Masliah, E.; Rockenstein, E.M.; Rall, G.F.; Abraham, C.R.; Mucke, L. Central nervous system damage produced by expression of the HIV-1 coat protein gp120 in transgenic mice. Nature 1994, 367, 188-193. [CrossRef] [PubMed]

37. Asquith, B.; Debacq, C.; Florins, A.; Gillet, N.; Sanchez-Alcaraz, T.; Mosley, A.; Willems, L. Quantifying lymphocyte kinetics in vivo using carboxyfluorein diacetate succinimidyl ester. Proc. Biol. Sci. 2006, 273, 1165-1171. [CrossRef] [PubMed]

38. Metges, C.C.; Yu, Y.M.; Cai, W.; Lu, X.M.; Wong, S.; Regan, M.M.; Ajami, A.; Young, V.R. Oxoproline kinetics and oxoproline urinary excretion during glycine- or sulfur amino acid-free diets in humans. Am. J. Physiol. Endocrinol. Metab. 2000, 278, E868-E876. [CrossRef] [PubMed]

39. Jackson, A.A.; Persaud, C.; Hall, M.; Smith, S.; Evans, N.; Rutter, N. Urinary excretion of 5-L-oxoproline (pyroglutamic acid) during early life in term and preterm infants. Arch. Dis. Child. 1997, 76, F152-F157. [CrossRef]

40. Lubert, S. Biochemistry, 4th ed.; Freeman and Company: New York, NY, USA, 1995; pp. 559-565, 614-623.

41. Warburg, O. On the origin of cancer cells. Science 1956, 123, 309-314. [CrossRef] [PubMed]

42. Koppenol, W.H.; Bounds, P.L.; Dang, C.V. Otto Warburg's contributions to current concepts of cancer metabolism. Nat. Rev. Cancer 2011, 11, 325-337. [CrossRef] [PubMed]

43. Gatenby and Gillies, R.J. Why do cancers have high aerobic glycolysis? Nat. Rev. Cancer 2004, 4, 891-899. [CrossRef] [PubMed]

44. Barré-Sinoussi, F.; Ross, A.L.; Delfraissy, J.F. Past present and future: 30 years of HIV research. Nat. Rev. Microbiol. 2013, 11, 877-883. [CrossRef] [PubMed]

45. Berger, E.A. HIV entry and tropism: The chemokine receptor connection. AIDS 1997, 11 (Suppl. A), S3-S6.

46. Wilen, C.B.; Tilton, J.C.; Doms, R.W. HIV: Cell binding and entry. Cold Spring Harb. Perspect. Med. $2012,2$. [CrossRef] [PubMed]

47. Chevigne, A.; Delhalle, S.; Counson, M.; Beaupain, N.; Rybicki, A.; Verschueren, C.; Staub, T.; Schmit, J.C.; Seguin-Devaux, C.; Deroo, S. Isolation of an HIV-1 neutralizing peptide mimicking the CXCR4 and CCR5 surface from the heavy-chain complementary determining region 3 repertoire of a viremic controller. AIDS 2016, 30, 377-382. [CrossRef] [PubMed]

48. Yadav, V.N.; Zamler, D.; Baker, G.J.; Kadiyala, P.; Erdreich-Epstein, A.; DeCarvalho, A.C.; Mikkelsen, T.; Castro, M.G.; Lowenstein, P.R. CXCR4 increases in-vivo glioma perivascular invasion and reduces radiation induced apoptosis: A genetic knockdown study. Oncotarget 2016, 7, 83701-83719. [CrossRef] [PubMed]

49. Rubin, J.B.; Kung, A.L.; Klein, R.S.; Chan, J.A.; Sun, Y.; Schmidt, K.; Kieran, M.W.; Luster, A.D.; Segal, R.A. A small-molecule antagonist of CXCR4 inhibits intracranial growth of primary brain tumors. Proc. Natl. Acad. Sci. USA 2003, 100, 13513-13518. [CrossRef] [PubMed]

50. Barbero, S.; Bonavia, R.; Bajetto, A.; Porcile, C.; Pirani, P.; Ravetti, J.L.; Zona, G.L.; Spaziante, R.; Florio, T.; Schettini, G. Stromal cell-derived factor 1alpha stimulates human glioblastoma cell growth through the activation of both extracellular signal-regulated kinases 1/2 and Akt. Cancer Res. 2003, 63, 1969-1974. [PubMed]

51. Gao, D.; Rahbar, R.; Fish, E.N. CCL5 activation of CCR5 regulates cell metabolism to enhance proliferation of breast cancer cells. Open Biol. 2016, 6. [CrossRef] [PubMed]

52. Chan, O.; Burke, J.D.; Gao, D.F.; Fish, E.N. The Chemokine CCL5 Regulates Glucose Uptake and AMP Kinase Signaling in Activated T Cells to Facilitate Chemotaxis. J. Biol. Chem. 2012, 287, 29406-29416. [CrossRef] [PubMed]

53. Mercurio, L.; Cecchetti, S.; Ricci, A.; Pacella, A.; Cigliana, G.; Bozzuto, G.; Podo, F.; Iorio, E.; Carpinelli, G. Phosphatidylcholine-specific phospholipase $\mathrm{C}$ inhibition down-regulates CXCR4 expression and interferes with proliferation, invasion and glycolysis in glioma cells. PLoS ONE 2017, 12, E0176108. [CrossRef] [PubMed] 
54. Munger, J.; Bajad, S.U.; Coller, H.A.; Shenk, T.; Rabinowitz, J.D. Dynamics of the cellular metabolome during human cytomegalovirus infection. PLoS Pathog. 2006, 2, e132. [CrossRef] [PubMed]

55. Yu, Y.; Clippinger, A.J.; Pierciey, FJ. Jr.; Alwine, J.C. Viruses and metabolism: Alterations of glucose and glutamine metabolism mediated by human cytomegalovirus. Adv. Virus Res. 2011, 80, 49-67. [CrossRef] [PubMed]

56. Chang, C.H.; Curtis, J.D.; Maggi, L.B.Jr.; Faubert, B.; Villarino, A.V.; O'Sullivan, D.; Huang, S.C.; van der Windt, G.J.; Blagih, J.; Qiu, J.; et al. Posttranscriptional control of T cell effector function by aerobic glycolysis. Cell 2013, 153, 1239-1251. [CrossRef] [PubMed]

57. Hegedus, A.; Kavanagh Williamson, M.; Huthoff, H. HIV-1 pathogenicity and virion production are dependent on the metabolic phenotype of activated CD4+ T-cells. Retrovirology 2014, 11, 98. [CrossRef] [PubMed]

58. Frauwirth, K.A.; Thompson, C.B. Regulation of T lymphocyte metabolism. J. Immunol. 2004, 172, 4661-4665. [CrossRef] [PubMed]

59. Van der Windt, G.J.; Pearce, E.L. Metabolic switching and fuel choice during T-cell differentiation and memory development. Immunol. Rev. 2012, 249, 27-42. [CrossRef] [PubMed]

60. Kuroda, K.; Fukuda, T.; Krstic-Demonacos, M.; Demonacos, C.; Okumura, K.; Isogai, H.; Hayashi, M.; Saito, K.; Isogai, E. miR-663a regulates growth of colon cancer cells, after administration of antimicrobial peptides, by targeting CXCR4-p21 pathway. BMC Cancer 2017, 17, 33. [CrossRef] [PubMed]

61. Huang, C.Y.; Fong, Y.C.; Lee, C.Y.; Chen, M.Y.; Tsai, H.C.; Hsu, H.C.; Tang, C.H. CCL5 increases lung cancer migration via PI3K, Akt and NF-kappaB pathways. Biochem. Pharmacol. 2009, 77, 794-803. [CrossRef] [PubMed]

62. Wang, S.W.; Wu, H.H.; Liu, S.C.; Wang, P.C.; Ou, W.C.; Chou, W.Y.; Shen, Y.S.; Tang, C.H. CCL5 and CCR5 interaction promotes cell motility in human osteosarcoma. PLoS ONE 2012, 7, e35101. [CrossRef]

63. Raman, D.; Sobolik-Delmaire, T.; Richmond, A. Chemokines in health and disease. Exp. Cell. Res. 2011, 317, 575-589. [CrossRef] [PubMed]

64. Pap, M.; Cooper, G.M. Role of glycogen synthase kinase-3 in the phosphatidylinositol 3-Kinase/Akt cell survival pathway. J. Biol. Chem. 1998, 273, 19929-19932. [CrossRef] [PubMed]

65. Stiles, B.; Gilman, V.; Khanzenzon, N.; Lesche, R.; Li, A.; Qiao, R.; Liu, X.; Wu, H. Essential role of AKT-1/protein kinase B alpha in PTEN-controlled tumorigenesis. Mol. Cell. Biol. 2002, 22, 3842-3851. [CrossRef] [PubMed]

66. Miyashita, K.; Kawakami, K.; Nakada, M.; Mai, W.; Shakoori, A.; Fujisawa, H.; Hayashi, Y.; Hamada, J.; Minamoto, T. Potential therapeutic effect of glycogen synthase kinase 3beta inhibition against human glioblastoma. Clin. Cancer Res. 2009, 15, 887-897. [CrossRef] [PubMed]

67. Sareddy, G.R.; Panigrahi, M.; Challa, S.; Mahadevan, A.; Babu, P.P. Activation of Wnt/beta-catenin/Tcf signaling pathway in human astrocytomas. Neurochem. Int. 2009, 55, 307-317. [CrossRef] [PubMed]

68. Yang, J.M.; Schiapparelli, P.; Nguyen, H.N.; Igarashi, A.; Zhang, Q.; Abbadi, S.; Amzel, L.M.; Sesaki, H.; Quinones-Hinojosa, A.; Iijima, M. Characterization of PTEN mutations in brain cancer reveals that pten mono-ubiquitination promotes protein stability and nuclear localization. Oncogene 2017, 36, 3673-3685. [CrossRef] [PubMed]

69. Adachi, J.; Ohbayashi, K.; Suzuki, T.; Sasaki, T. Cell cycle arrest and astrocytic differentiation resulting from PTEN expression in glioma cells. J. Neurosurg. 1999, 91, 822-830. [CrossRef] [PubMed]

70. De Saldanha da Gama Fischer, J.; Liao, L.; Carvalho, P.C.; Barbosa, V.C.; Domont, G.B.; da Gloria da Costa Carvalho, M.; Yates, J.R. Dynamic Proteomic Overview of Glioblastoma Cells (A172) Exposed to Perillyl Alcohol. J. Proteomics 2010, 73, 1018-1027. [CrossRef] [PubMed]

71. Steták, A.; Veress, R.; Ovádi, J.; Csermely, P.; Kéri, G.; Ullrich, A. Nuclear translocation of the tumor marker pyruvate kinase M2 induces programmed cell death. Cancer Res. 2007, 67, 1602-1608. [CrossRef] [PubMed]

72. Christofk, H.R.; Vander Heiden, M.G.; Wu, N.; Asara, J.M.; Cantley, L.C. Pyruvate kinase M2 is a phosphotyrosine-binding protein. Nature 2008, 452, 181-186. [CrossRef] [PubMed]

73. Hitosugi, T.; Kang, S.; Vander Heiden, M.G.; Chung, T.-W.; Elf, S.; Lythgoe, K.; Dong, S.; Lonial, S.; Wang, X.; Chen, G.Z.; et al. Tyrosine phosphorylation inhibits PKM2 to promote the Warburg effect and tumor growth. Sci. Signal. 2009, 2, Ra73. [CrossRef] [PubMed]

74. Shimada, N.; Shinagawa, T.; Ishii, S. Modulation of M2-type pyruvate kinase activity by the cytoplasmic PML tumor suppressor protein. Genes Cells 2008, 13, 245-254. [CrossRef] [PubMed] 
75. Barger, J.F.; Plas, D.R. Balancing biosynthesis and bioenergetics: Metabolic programs in oncogenesis. Endocr. Relat. Cancer 2010, 17, R287-R304. [CrossRef] [PubMed]

76. Alfarouk, K.O.; Verduzco, D.; Rauch, C.; Muddathir, A.K.; Adil, H.B.; Elhassan, G.O.; Ibrahim, M.E.; David Polo Orozco, J.; Cardone, R.A.; Reshkin, S.J.; Harguindey, S. Glycolysis, tumor metabolism, cancer growth and dissemination. A new $\mathrm{pH}$-based etiopathogenic perspective and therapeutic approach to an old cancer question. Oncoscience 2014, 1, 777-802. [CrossRef] [PubMed]

77. Jurica, M.S.; Mesecar, A.; Heath, P.J.; Shi, W.; Nowak, T.; Stoddard, B.L. The allosteric regulation of pyruvate kinase by fructose-1,6-bisphosphate. Structure 1998, 6, 195-210. [CrossRef]

78. Anastasiou, D.; Yu, Y.; Israelsen, W.J.; Jiang, J.K.; Boxer, M.B.; Hong, B.S.; Tempel, W.; Dimov, S.; Shen, M.; Jha, A.; et al. Pyruvate kinase M2 activators promote tetramer formation and suppress tumorigenesis. Nat. Chem. Biol. 2012, 8, 839-847. [CrossRef] [PubMed]

79. Chaneton, B.; Hillmann, P.; Zheng, L.; Martin, A.C.L.; Maddocks, O.D.K.; Chokkathukalam, A.; Coyle, J.E.; Jankevics, A.; Holding, F.P.; Vousden, K.H.; et al. Serine is a natural ligand and allosteric activator of pyruvate kinase M2. Nature 2012, 491, 458-462. [CrossRef] [PubMed]

80. Possemato, R.; Marks, K.M.; Shaul, Y.D.; Pacold, M.E.; Kim, D.; Birsoy, K.; Sethumadhavan, S.; Woo, H.K.; Jang, H.G.; Jha, A.K.; et al. Functional genomics reveal that the serine synthesis pathway is essential in breast cancer. Nature 2011, 476, 346-350. [CrossRef] [PubMed]

81. Pollari, S.; Käkönen, S.M.; Edgren, H.; Wolf, M.; Kohonen, P.; Sara, H.; Guise, T.; Nees, M.; Kallioniemi, O. Enhanced serine production by bone metastatic breast cancer cells stimulates osteoclastogenesis. Breast Cancer Res. Treat. 2011, 125, 421-430. [CrossRef] [PubMed]

82. Locasale, J.W.; Grassian, A.R.; Melman, T.; Lyssiotis, C.A.; Mattaini, K.R.; Bass, A.J.; Heffron, G.; Metallo, C.M.; Muranen, T.; Sharfi, H.; et al. Phosphoglycerate dehydrogenase diverts glycolytic flux and contributes to oncogenesis. Nat. Genet. 2011, 43, 869-874. [CrossRef] [PubMed]

83. Amelio, I.; Cutruzzolá, F.; Antonov, A.; Agostini, M.; Melinoemail, G. Serine and glycine metabolism in cancer. Trends Biochem. Sci. 2014, 39, 191-198. [CrossRef] [PubMed]

84. Wang, Q.; Beaumont, K.A.; Otte, N.J.; Font, J.; Bailey, C.G.; van Geldermalsen, M.; Sharp, D.M.; Tiffen, J.C.; Ryan, R.M.; Jormakka, M.; et al. Targeting glutamine transport to suppress melanoma cell growth. Int. J. Cancer 2014, 135, 1060-1071. [CrossRef] [PubMed]

85. Hassanein, M.; Hoeksema, M.D.; Shiota, M.; Qian, J.; Harris, B.K.; Chen, H.; Clark, J.E.; Alborn, W.E.; Eisenberg, R.; Massion, P.P. SLC1A5 mediates glutamine transport required for lung cancer cell growth and survival. Clin. Cancer Res. 2013, 19, 560-570. [CrossRef] [PubMed]

86. Hassanein, M.; Qian, J.; Hoeksema, M.D.; Wang, J.; Jacobovitz, M.; Ji, X.; Harris, F.T.; Harris, B.K.; Boyd, K.L.; Chen, H.; et al. Targeting SLC1A5-mediated glutamine dependence in non-small cell lung cancer. Int. J. Cancer 2015, 137, 1587-1597. [CrossRef] [PubMed]

87. Wang, Q.; Hardie, R.A.; Hoy, A.J.; van Geldermalsen, M.; Gao, D.; Fazli, L.; Sadowski, M.C.; Balaban, S.; Schreuder, M.; Nagarajah, R.; et al. Targeting ASCT2-mediated glutamine uptake blocks prostate cancer growth and tumour development. J. Pathol. 2015, 236, 278-289. [CrossRef] [PubMed]

88. Willems, L.; Jacque, N.; Jacquel, A.; Neveux, N.; Maciel, T.T.; Lambert, M.; Schmitt, A.; Poulain, L.; Green, A.S.; Uzunov, M.; et al. Inhibiting glutamine uptake represents an attractive new strategy for treating acute myeloid leukemia. Blood 2013, 122, 3521-3532. [CrossRef] [PubMed]

89. Van Geldermalsen, M.; Wang, Q.; Nagarajah, R.; Marshall, A.D.; Thoeng, A.; Gao, D.; Ritchie, W.; Feng, Y.; Bailey, C.G.; Deng, N.; et al. 2015ASCT2/SLC1A5 controls glutamine uptake and tumour growth in triple-negative basal-like breast cancer. Oncogene 2016, 35, 3201-3208. [CrossRef] [PubMed]

90. Pecqueur, C.; Oliver, L.; Oizel, K.; Lalier, L.; Vallette, F.M. Targeting Metabolism to Induce Cell Death in Cancer Cells and Cancer Stem Cells. Int. J. Cell. Biol. 2013, 2013, 805975. [CrossRef] [PubMed]

91. Gao, P.; Tchernyshyov, I.; Chang, T.C.; Lee, Y.S.; Kita, K.; Ochi, T.; Zeller, K.I.; De Marzo, A.M.; Van Eyk, J.E.; Mendell, J.T.; et al. C-Myc suppression of miR-23a/b enhances mitochondrial glutaminase expression and glutamine metabolism. Nature 2009, 458, 762-765. [CrossRef] [PubMed]

92. Hawkins, R.A.; Vina, J.R. How Glutamate Is Managed by the Blood-Brain Barrier. Biology 2016, 5, 37. [CrossRef] [PubMed]

93. Miyauchi, S.; Gopal, E.; Babu, E.; Srinivas, S.R.; Kubo, Y.; Umapathy, N.S.; Thakkar, S.V.; Ganapathy, V.; Prasad, P.D. Sodium-coupled electrogenic transport of pyroglutamate (5-oxoproline) via SLC5A8, a monocarboxylate transporter. Biochim. Biophys. Acta 2010, 1798, 1164-1171. [CrossRef] [PubMed] 
94. Liu, W.; Le, A.; Hancock, C.; Lane, A.N.; Dang, C.V.; Fan, T.W.; Phang, J.M. Reprogramming of proline and glutamine metabolism contributes to the proliferative and metabolic responses regulated by oncogenic transcription factor c-MYC. Proc. Natl. Acad. Sci. USA 2012, 109, 8983-8988. [CrossRef] [PubMed]

95. Phang, J.M.; Liu, W.; Hancock, C.N.; Fischer, J.W. Proline metabolism and cancer: Emerging links to glutamine and collagen. Curr. Opin. Clin. Nutr. Metab. Care 2015, 18, 71-77. [CrossRef] [PubMed]

96. Liu, W.; Hancock, C.N.; Fischer, J.W.; Harman, M.; Phang, J.M. Proline biosynthesis augments tumor cell growth and aerobic glycolysis: Involvement of pyridine nucleotides. Sci. Rep. 2015, 5, 17206. [CrossRef] [PubMed]

97. Reversade, B.; Escande-Beillard, N.; Dimopoulou, A.; Fischer, B.; Chng, S.C.; Li, Y.; Tham, P.Y.; Kayserili, H.; Al-Gazali, L.; Shahwan, M.; et al. Mutations in PYCR1 cause cutis laxa with progeroid features. Nat. Genet. 2009, 41, 1016-1021. [CrossRef] [PubMed]

98. Baenke, F.; Peck, B.; Miess, H.; Schulze, A. Hooked on fat: The role of lipid synthesis in cancer metabolism and tumour development. Dis. Model. Mech. 2013, 6, 1353-1363. [CrossRef] [PubMed]

99. Medes, G.; Thomas, A.; Weinhoise, S. Metabolism of neoplastic tissue. IV. A study of lipid synthesis in neoplastic tissue slices in vitro. Cancer Res. 1953, 13, 27-29. [PubMed]

100. Santos, C.R.; Schulze, A. Lipid metabolism in cancer. FEBS J. 2012, 279, 2610-2623. [CrossRef] [PubMed]

101. Menendez, J.A.; Lupu, R. Fatty acid synthase and the lipogenic phenotype in cancer pathogenesis. Nat. Rev. Cancer 2007, 7, 763-777. [CrossRef] [PubMed]

102. Opitz, C.A.; Litzenburger, U.M.; Sahm, F.; Ott, M.; Tritschler, I.; Trump, S.; Schumacher, T.; Jestaedt, L.; Schrenk, D.; Weller, M.; et al. An endogenous tumour-promoting ligand of the human aryl hydrocarbon receptor. Nature 2011, 478, 197-203. [CrossRef] [PubMed]

103. Platten, M.; Wick, W.; Van den Eynde, B.J. Tryptophan catabolism in cancer: Beyond IDO and tryptophan depletion. Cancer Res. 2012, 72, 5435-5440. [CrossRef] [PubMed]

104. Mezrich, J.D.; Fechner, J.H.; Zhang, X.; Johnson, B.P.; Burlingham, W.J.; Bradfield, C.A. An interaction between kynurenine and the aryl hydrocarbon receptor can generate regulatory T cells. J. Immunol. 2010, 185, 3190-3198. [CrossRef] [PubMed]

105. George, C. Prendergast Cancer: Why tumours eat tryptophan. Nature 2011, 478, 192-194. [CrossRef]

106. Uyttenhove, C.; Pilotte, L.; Théate, I.; Stroobant, V.; Colau, D.; Parmentier, N.; Boon, T.; Van den Eynde, B.J. Evidence for a tumoral immune resistance mechanism based on tryptophan degradation by indoleamine 2,3-dioxygenase. Nat. Med. 2003, 9, 1269-1274. [CrossRef] [PubMed]

107. Garzon-Muvdi, T.; Schiapparelli, P.; Ap Rhys, C.; Guerrero-Cazares, H.; Smith, C.; Kim, D.H.; Kone, L.; Farber, H.; Lee, D.Y.; An, S.S.; et al. Regulation of brain tumor dispersal by NKCC1 through a novel role in focal adhesion regulation. PLoS Biol. 2012, 10. [CrossRef] [PubMed]

108. Schiapparelli, P.; Guerrero-Cazares, H.; Magaña-Maldonado, R.; Hamilla, S.M.; Ganaha, S.; Goulin Lippi Fernandes, E.; Huang, C.H.; Aranda-Espinoza, H.; Devreotes, P.; Quinones-Hinojosa, A. NKCC1 Regulates Migration Ability of Glioblastoma Cells by Modulation of Actin Dynamics and Interacting with Cofilin. EBioMedicine 2017, 21, 94-103. [CrossRef] [PubMed]

109. Rolón-Reyes, K.; Kucheryavykh, Y.V.; Cubano, L.A.; Inyushin, M.; Skatchkov, S.N.; Eaton, M.J.; Harrison, J.K.; Kucheryavykh, L.Y. Microglia Activate Migration of Glioma Cells through a Pyk2 Intracellular Pathway. PLoS ONE 2015, 10, e0131059. [CrossRef] [PubMed]

110. Dettmer, K.; Nurnberger, N.; Kaspar, H.; Gruber, M.A.; Almstetter, M.F.; Oefner, P.J. Metabolite extraction from adherently growing mammalian cells for metabolomics studies: Optimization of harvesting and extraction protocols. Anal. Bioanal. Chem. 2011, 399, 1127-1139. [CrossRef] [PubMed]

111. Babushok, V.I.; Linstrom, P.J.; Reed, J.J.; Zenkevich, I.G.; Brown, R.L.; Mallard, W.G.; Stein, S.E. Development of a database of gas chromatographic retention properties of organic compounds. J. Chromatogr. A 2007, 1157, 414-421. [CrossRef] [PubMed]

(C) 2018 by the authors. Licensee MDPI, Basel, Switzerland. This article is an open access article distributed under the terms and conditions of the Creative Commons Attribution (CC BY) license (http:/ / creativecommons.org/licenses/by/4.0/). 